\title{
STATE ACTION PROBLEMS
}

\author{
Christian Turner*
}

\begin{abstract}
The state action doctrine is a mess. Explanations for why federal courts sometimes treat the private actions of private parties as public actions subject to the Constitution, as the Supreme Court did in Shelley v. Kraemer, are either vastly over-inclusive or fail to explain our law and values. A better approach is to understand the state action doctrine in institutional terms. I introduce a two-step, institutionally focused state action theory that is a natural consequence of a broader public-private theory of legal systems. In the first step, a court identifies a "state action problem," meaning a privately made law that is poorly governed by the ordinary rules governing the making of contracts. If a court finds a state action problem, it proceeds to the second step and decides whether courts have superior capacity to remedy the problem than do other governmental institutions. This theory captures important intuitions about the public regulation of private lawmaking that other approaches either ignore or fail to ground theoretically. In addition, it helps to justify why racial discrimination is often a decisive fact in finding state action, explains why the doctrine is rarely invoked, and provides a firm, theoretical foundation for a doctrine otherwise adrift in search of guiding principles.
\end{abstract}

INTRODUCTION 282

I. EXISTING DOCTRINE AND APPROACHES 287

II. The Institutional TheORY OF STATE ACTION: AN ALTERNATIVE APPROACH .............................................2294

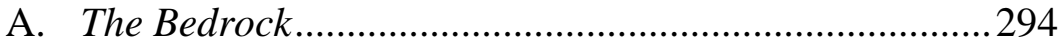

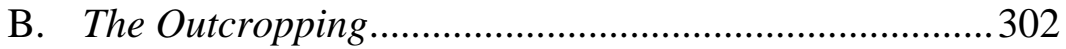

1. The Nature of the Public-Private Inquiry ...............303

2. The First Step: State Action Problems ...................305

a. Covenants........................................................308

b. Common-Interest Communities.......................310

* Associate Professor Law, University of Georgia School of Law. For their help, criticism, and encouragement, I wish to thank Dan Coenen, Harlan Cohen, Christopher Elmendorf, Matthew Hall, Ethan Leib, Joseph Miller, Lori Ringhand, Albert Yoon, , and the participants of the University of Georgia Law School's junior faculty retreat. I would also like to thank the organizers and participants at the 2012 meeting of the Association for Law, Property, and Society at Georgetown University Law Center, where this paper was first delivered. For their research assistance, I would like to thank Barclay Hendrix, Matthew Noller, and Fritz Vaughan. 
3. The Second Step: Judicial Intervention

III. A COMPARISON OF THE THEORIES IN ACTION

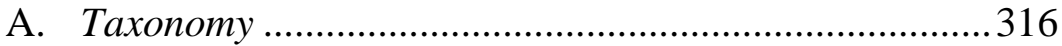

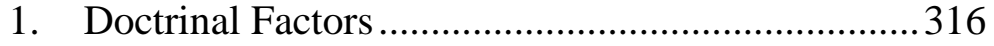

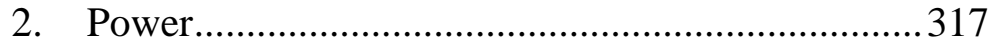

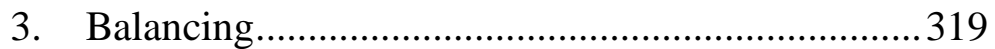

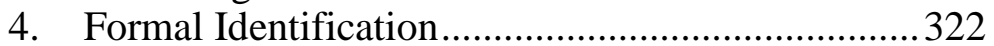

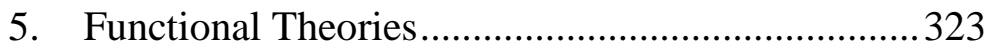

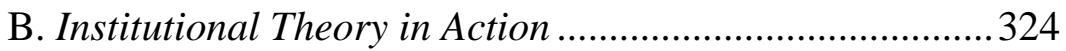

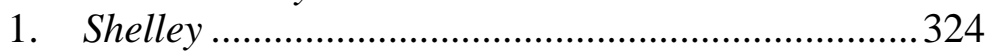

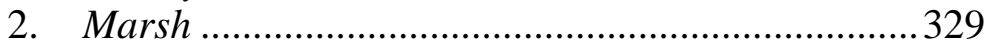

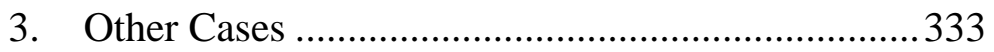

4. Private Action Problems .........................................336

CONCLUSION

338

\section{INTRODUCTION}

Was Shelley v. Kraemer correctly decided ${ }^{1}$ The Constitution plainly prohibits states from imposing racially discriminatory laws, but does it forbid private parties from entering discriminatory covenants? Answer yes, and one needs to explain why a rule addressed to states should constrain agreements between private individuals - and why it does not apply to all private conduct. Answer no, and the task becomes justifying inaction in the face of entrenched, private apartheid. Our dinner invitations, marriage proposals, and even business ventures certainly must be immune to at least some of the constitutional law that requires public actors to afford equal treatment, due process, and respect for all viewpoints. At the same time, widespread, private racism can lead to an unequal, caste-like society as surely as statutes commanding it be so.

In Shelley, the Supreme Court chose the path of action, deciding that it was a violation of the Equal Protection Clause for Missouri courts to enforce racially discriminatory private covenants, no matter the covenants' apparent compliance with state law and the inapplicability of any federal statute. ${ }^{2}$ The enforcement by public courts was the "state action" that the Constitution regulated and found wanting. But if the substance of a private agreement is constrained by the Constitution merely because a court enforces the agreement, then there is no area of private contract law left unregulated by the Constitution. Every private

1. 334 U.S. 1 (1948).

2. Id. at $19-23$. 
actor is subject to the constraints on public actors. ${ }^{3}$ And yet, if private actors are never subject to constitutional regulation, then powerful coalitions of private individuals are free to use their coercive capacity to create, for example, a de facto system of racist zoning. Shelley must be wrong, and yet it must be right.

Take another case turning on the presence of state action: May a corporation forcibly eject a religious speaker from streets the corporation owns in a town the corporation owns because it wishes to suppress such speech? Again, private citizens violate each other's free speech rights all the time, choosing associates and houseguests on the basis of social, political, or religious viewpoints. Only the State is constitutionally prohibited from discriminating in this way. Nonetheless, the Supreme Court, in Marsh v. Alabama, decided that a company that owns an entire town must allow speakers to exercise the speech rights they would have in an ordinary, publicly owned town. ${ }^{4}$ Of course, racially discriminatory covenants and company-owned towns are not the only private spheres in which the state action question is problematic. From privately operated political primaries to protests at large shopping malls, some of the most puzzling cases in our constitutional law turn on whether private entities ought to be treated as if they were an arm of the State.

A principle that explains or refutes these decisions has proved elusive. The line of state action opinions has been criticized as incoherent, ungrounded, and insincere. The Supreme Court itself has acknowledged that the "cases deciding when private action might be deemed that of the state have not been a model of consistency." Vikram Amar has more candidly stated that "[i]t might be fair to call the area a mess. " $\mathrm{I}$ would go further. It is a mess.

Why are these cases difficult? Why depart at all from using an actor's formal status as a rule-like state action threshold? Why is a more flexible state action doctrine, such as the one we have, desirable and yet so hard to fashion? The answer to these questions lies in better understanding the heart of the problem, the dichotomy that is the bedrock of our legal system: the public-private distinction.

3. See, e.g., Carol Rose, Property Stories: Shelley v. Kraemer, in ProPERTY STORIES 169, 194 (Gerald Korngold \& Andrew P. Morriss eds., 2004) ("Shelley seemed simply to assert that judicial enforcement of covenants is 'state action'; but this raises the familiar problem of constitutionalizing every private civil conflict that appears in court.").

4. 326 U.S. 501, 507-09 (1946).

5. Lebron v. Nat'l R.R. Passenger, 513 U.S. 374, 378 (1995) (quoting Edmonson v. Leesville Concrete Co., 500 U.S. 614, 632 (1991)) (O’Connor, J., dissenting).

6. Vikram David Amar, The NCAA as Regulator, Litigant, and State Actor, 52 B.C. L. REV. 415, 416 (2011). 
The morass of the state action doctrine is almost entirely a product of conflicting intuitions concerning what is public, or somehow of the State, and what is private, or not of the State.

In the state action cases, the basic structure of legal systems is exposed, and the most essential and divisive political question-the proper division of authority between the collective and the individuals that compose it-starkly demands an answer. If undisciplined, this inquiry can be so uncertain that any rule that depends on identifying what is public, or state action, and what is private action is easily transformed into a vessel for the imposition of raw policy preferences. In response to any argument that a thing is private, one can always argue that it is public.

There is, however, a better way than muddling through, one that helps elucidate the purposes the state action doctrine serves and the policies that are important when choosing how to apply it. To find it, we must first understand that the question is not whether a regulated entity is public or private in the undifferentiated abstract, but whether it exhibits the particular private or public characteristics at which the secondary rules regulating its lawmaking power are targeted. ${ }^{7}$

Any legal system, whether or not based in part on a written constitution, maintains two bodies of law that may be characterized as fundamental Constitutional Law. "Private Constitutional Law" comprises the criteria for creating and reviewing privately enacted law, including ordinary contracts. In our system, this includes the doctrines of offer and acceptance and of unconscionability. Private Constitutional Law responds to the stereotypical institutional difficulties of private lawmaking bodies, including self-interestedness. In contrast, "public

7. By secondary rules, I mean the rules that govern the creation, change, and use of the primary rules that govern behavior directly. As H.L.A. Hart put it:

\begin{abstract}
Under rules of the one type, which may well be considered the basic or primary type, human beings are required to do or abstain from certain actions, whether they wish to or not. Rules of the other type are in a sense parasitic upon or secondary to the first; for they provide that human beings may by doing or saying certain things introduce new rules of the primary type, extinguish or modify old ones, or in various ways determine their incidence or control their operations. Rules of the first type impose duties; rules of the second type confer powers, public or private.
\end{abstract}

H.L.A. HART, The CONCEPT OF LAW 81 (2d ed. 1994). The written U.S. Constitution governs, among other things, the creation and change of laws by the Congress. Its provisions related to legislature composition, the enactment of laws, and right-based prohibitions on the content of laws are all secondary rules. So too, state contract law setting forth offer and acceptance and other doctrines as criteria for the validity of a contract are secondary rules. See also Christian Turner, Law's Public/Private Structure, 39 FLA. St. L. REv. 1003, 1013-14(2012).

8. See Turner, supra note 7, at 1013-16; see also infra Part III. 
Constitutional Law" governs the creation and review of publicly enacted law. The governance of congressional lawmaking in our own written Constitution is a part of this law. Public Constitutional Law, because it governs the making of law that will bind others without their consent, is responsive to the stereotypical problems of public agents.

Viewing legal systems in this way, it becomes clear that the state action cases raise a kind of "Categorization Problem," a problem of choosing between alternative bodies of secondary rules to govern an institution. A legal system encounters a type of Categorization Problem that I call a "state action problem" when the characteristics relevant to a formally private entity's lawmaking competency more resemble those of public institutions. In such a case, private Constitutional Law will be ill-suited to prevent unacceptably bad decisions. This is because private Constitutional Law has been tuned to respond to the typical failings of private entities, not those of public entities more similar to the actor with respect to the decision at issue.

To put it differently, the legal constraints on contracting parties are tuned to the problems private lawmakers typically encounter. Some acts of private lawmaking are, however, far more like public lawmaking, for which there are different types of constraints addressed to the stereotypical problems that attend making laws that bind nonconsenting others. Private actors engaged in the equivalent of public legislation therefore present a state action problem, meaning that they are poorly governed by the usual private secondary rules.

But finding a state action problem is only the first step in applying a sensible state action doctrine. The existence of such a problem does not imply that the only solution is to empower a judge to impose public Constitutional Law on the private actor. Rather, state action problems create tension in a legal system that may be resolved in a number of ways. Federal or state legal systems, by legislation or common law, can supply appropriate governance of categories of state action problems by means other than formal application of their public constitutional rules. For example, the rules passed by homeowner associations, despite their private source, are routinely put to a higher, more public-like standard of review than are ordinary contractual provisions. Such review, as will be discussed further, is a solution to a clear state action problem, but one that does not rely on wholesale classification of the association as a public lawmaker.

It is only when (1) the mismatch between the governing private metalaw and private lawmaker is severe and (2) the political (and other) branches within the legal system have failed to supply a solution and are peculiarly disabled from doing so that courts, as a last resort, consider declaring that the private actor is in fact a "state actor." The state action doctrine as we know it is, therefore, a body of law intended 
to solve a coupled institutional problem. First, is the lawmaking at issue, though formally private, so unlike stereotypical private conduct or lawmaking that the institutional controls of ordinary, private Constitutional Law are a bad fit? Second, is there a reason for courts to attempt to solve this problem themselves by imposing public, rather than private, Constitutional Law? ${ }^{9}$

This two-dimensional understanding of the state action doctrine solves the doctrinal puzzle. It tells us, for example, why race is such a salient factor in state action cases-why the result in Shelley is principled and not just the exercise of judicial power to achieve a political objective. It also tells us why Shelley would and should come out differently were other constitutional values than racial equality at stake. It does so by analyzing institutional competence, rather than substance. Perhaps counterintuitively, institutional analysis better focuses legal debate on the heart of the normative disagreements that make these cases intuitively difficult: the line between the individual and the collective and the power to decide where to draw the line.

In Part I of this Article, I briefly describe the state action doctrine and its difficulties. To explain the institutional approach, I then review the public-private theory of legal systems and define, within that theory, the two-step state action inquiry. In Part III, I contrast this structural theory of state action with more traditional theories and study their varying applications to some canonical state action cases.

$$
* * *
$$

The public-private distinction defines the underlying structure of legal systems. Properly understood and focused, it defines our legal bedrock, giving shape to legal systems while remaining mostly unseen, buried under an apparently disordered surface. The state action doctrine represents the ragged, rocky outcroppings of this bedrock. State action cases are difficult to classify, unrecognizable, and hard to square with other doctrine. They are the puzzling cases that challenge the most basic principles of lawmaking and adjudication-principles that normally lie safely under the surface, intuited but rarely analyzed, in most of our legal landscape. If we want to understand these hidden principles better,

9. This is a more general theory of state action than most. All legal systems encounter state action problems, as they all must grapple with categorizing lawmaking institutions to be governed by public or private metalaw. The first step of the theory I advance here, the identification of state action problems, does not depend on the legal system's having institutions that are like legislatures or courts. Only the theory's second step is specially adapted to our own structure, depending as it does on a legal system's welfare-orientation and division of power between institutions that resemble courts and legislatures in the relevant respects. 
then we should, like geologists, train our attention on the outcroppings that seem to defy all the normal rules.

\section{EXISTING DOCTRINE AND APPROACHES}

The state action doctrine deals with a group of cases that seem to contradict ordinary judicial experience. A court will have before it a private actor, but there exists some reason to think our Constitution ought to apply to this actor as it does against public actors. Perhaps he has suppressed speech or discriminated in a manner that is not forbidden by statutes or other laws targeted at private individuals. Nonetheless, and for reasons we will endeavor to understand, an unusual argument seems plausible, an argument normally foreign to litigation among private parties: that the written Constitution provides a reason to forbid the private conduct at issue. The doctrinal problem has been to construct rules and standards to guide the decision whether it does.

The Supreme Court long has labored to construct such a framework. The catholic nature of its efforts was illustrated in Brentwood Academy $v$. Tennessee Secondary School Athletic Ass' $n .^{10}$ There, the Court described the state action doctrine as a search for a "close nexus between the State and the challenged action." 11 Stressing that the doctrine contains no clear necessary or sufficient conditions, the Court summarized various factors that have at times been found controlling. ${ }^{12}$

It is important first of all to distinguish among the cases that fall under the state action rubric. Only some of these raise the Categorization Problem with which this Article is concerned. For example, the Court has stated in several cases that the key to finding state action lies in determining "when it can be said that the State is responsible for the specific conduct of which the plaintiff complains.", This test, though conceptually appealing, speaks only to cases in which the problem is with governmental conduct, perhaps because of its contribution to invidious private conduct. Unless stripped of meaning, it does nothing to explain a finding of state action in the cases that concern us here-cases like Shelley, Marsh, or Terry v. Adams, ${ }^{14}$ in

10. 531 U.S. 288 (2001).

11. Id. at 295-96 (quoting Jackson v. Metro. Edison Co., 419 U.S. 345, 351 (1974) (internal quotation marks omitted)).

12. Id. These factors include State participation through: (1) its "coercive power," (2) the provision of overt or covert "significant encouragement," (3) involvement as a "joint" actor, (4) control of the private actor as an agency, (5) delegation of a public function, or (6) "entwine[ment]" with the private actor, either through its policies or through "management or control." Id. at 296.

13. Blum v. Yaretsky, 457 U.S. 991, 1004 (1982).

14. See Terry v. Adams, 345 U.S. 461, 475-77 (1953) (holding that the election process of the private Jaybird Party violated the Fifteenth Amendment, even though the process was not 
which the state's participation was confined to upholding private agreements or rules and, in doing so, omitting more stringent regulations. If judicial enforcement of a private agreement is enough to say that the court - and by extension, the state - is "responsible" for the specific conduct, then there is no serious limitation to what may constitute state action. Every private agreement a court attempted to enforce would be reviewed for its constitutionality.

But "responsibility" as a criterion for state action is problematic even if it could be given a reasonably certain meaning that draws a far more modest line. After all, if the problem in a case is the State's responsibility, rather than the public-like character of the private actor, it would seem more logical to target the State itself - to seek an end to the State's conduct that is, in fact, "responsible for the specific conduct of which the plaintiff complains." And yet, the remedy for the State's responsibility is typically in the form of a judgment against the private defendant, not the State. Why is this?

Progress in this area depends at the outset on understanding that not all state action cases are the same. There is a class of cases involving actual conduct by government agents to aid a private party, resulting in injuries to plaintiffs that would surely be unconstitutional if caused by the government agents directly. Public agents are surely regulated according to public Constitutional Law, and I would treat the claims of plaintiffs in such cases as complaints directed at stopping the government's own conduct.

For example, in Burton v. Wilmington Parking Authority, ${ }^{15}$ the constitutional claim should have been against the government for its own hosting of a racially discriminatory tenant when it had the power not to do so. Under the theory I will develop here, the tenant would not be susceptible to constitutional regulation directly, as the case does not involve a state action problem. ${ }^{16}$ But that does not mean that the

regulated by the State); Shelley v. Kraemer, 334 U.S. 1, 19-21 (1948) (holding that state courts' enforcement of racist restrictive covenants constituted state action for purposes of the Fourteenth Amendment); Marsh v. Alabama, 326 U.S. 501, 504-09 (1946) (holding that a state trespassing statute preventing distribution of religious materials on a town's sidewalk was unconstitutional, even though the sidewalk was part of a privately-owned company town).

15. 365 U.S. 715, 716-17 (1961) (finding unconstitutional state action where a private tenant of a state agency operated a cafe in the agency's public parking garage in a facially racially discriminatory manner).

16. There is, I admit, some uncertainty here. But whether or not the much more difficult claim can be made that the Court should treat the private actor as a public actor on account of the state action doctrine, the point here is that there is an entirely separate claim that the governmental parking authority itself acted unconstitutionally in continuing to lease out public space that was subject to racially discriminatory operations. Mixing the question of unconstitutional governmental conduct with the separate question of the public character of the 
Constitution has nothing to say about the dispute in that case. The problem in Burton was with formal government support of discrimination, not with a private actor that is so coercive, powerful, or otherwise public-like that constitutional regulation of it, directly, is appropriate. $^{17}$

I classify cases involving perhaps ordinary private actors whose conduct is questioned because of actual governmental support or control as "find the state" cases. ${ }^{18}$ I do not venture here to improve the analysis of these cases, cases I believe should turn on the constitutional propriety of whatever it is that the government is doing in support. The question is not so much one of whether the private party is a state actor, although government control could lead a court to find that a putatively private party is a state agent for constitutional purposes. Rather, the question is whether those actions that are concededly those of the state are unconstitutional. Let us for now, though, leave such cases behind. ${ }^{19}$ While they involve their own difficult problems of line drawing, agency, and competing conceptions of governmental duties, they do not raise the more fundamental issue of assessing the appropriate role and character of the public-private distinction in classifying actors, as the most difficult state action cases do.

This Article is concerned with state action cases in which the complaint is only with the private party's own conduct, as to which there is some reason to think public Constitutional Law is the appropriate governing regime. And the question I ask is what reason that should be. The Court's doctrine has been promiscuous in

actor leads to confusion.

17. Which of these adjectives matter, and why, is the topic of the next Part.

18. When teaching state action to students, I have sometimes referred to the theory behind these "find the state" cases using the regrettably and increasingly outmoded term "Scooby Doo theory." Under such a theory, a court will endeavor to pull back the mask of the private actor and reveal the face of the State; the private actor then declaring that he or she would have gotten away with it but for the pesky plaintiffs.

19. I include in this category cases such as Lebron v. National Railroad Passenger, 513 U.S. 374 (1995), San Francisco Arts \& Athletics, Inc. v. U.S. Olympic Committee, 483 U.S. 522 (1987), and Rendell-Baker v. Kohn, 457 U.S. 830 (1982). In each of these, the gravamen of the state action litigation theory was the nature of the government's involvement. See Lebron, 513 U.S. at 398-400 (finding Amtrak, as a government-created and -controlled corporation, to be a state actor); S.F. Arts \& Athletics, Inc., 483 U.S. at 543-47 (finding that the U.S. Olympic Committee is a private actor despite receipt of government favors); Rendell-Baker, 457 U.S. at 839-43 (finding a private school to be a private actor despite receipt of public funds). As I have stated, it would be better to view these cases as raising questions about the constitutionality of the government's aid of private organizations that carry out what would be unconstitutional activities if the government did them directly. That is a different question than whether the private actor is so specially situated, again in ways we will seek to uncover, that constitutional regulation as if the private actor were a governmental entity is appropriate. 
entertaining a number of intuitive stances, for it is difficult to call them theories, to reach results in difficult cases. ${ }^{20}$

The cases leading up to Justice Souter's summary in Brentwood further illustrate that there is no set of circumstances, much less a principle establishing such a set, that is necessary or sufficient to find state action. The Court found state action when state courts enforced racially discriminatory private covenants, ${ }^{21}$ when a company town ejected a religious speaker, ${ }^{22}$ and when a private group held a statewide primary that had no formal binding effect but was used to select political candidates. ${ }^{23}$ It has refused to find state action when a monopoly provider of electrical power cut service without what the plaintiff claimed was the process due, ${ }^{24}$ when a private club used racially discriminatory membership policies, ${ }^{25}$ and when a private warehouse sold an evicted apartment dweller's belongings without her consent. ${ }^{26}$ And it has reversed itself on whether shopping malls that are open to the public but discriminate among speakers have engaged in state action. $^{27}$

In reaching these decisions, the Court has adverted to the potential salience of a private actor's monopoly power, ${ }^{28}$ the enforcement by public courts as a kind of public ratification, ${ }^{29}$ the public nature of the private actor, ${ }^{30}$ the relative weights of the rights on either side, ${ }^{31}$ a more generalized "nexus" of some sort between the actor and the State, ${ }^{32}$ and a number of other arguments. Sometimes these kinds of facts have been found decisive, sometimes unavailing. But it is unclear which facts truly matter, how much they matter, or why they matter. The problem is not only that the set of salient facts is not defined. It is that there is no

20. See, e.g., Ronald J. Krotoszynski, Jr., Back to the Briarpatch: An Argument in Favor of Constitutional Meta-Analysis in State Action Determinations, 94 Mich. L. REv. 302, 303-04 (1995) (explaining that the Supreme Court has developed three state action tests, each difficult to apply and of little help in solving the inconsistency of the state action doctrine).

21. Shelley v. Kraemer, 334 U.S. 1, 20 (1948).

22. Marsh v. Alabama, 326 U.S. 501, 509 (1946).

23. Terry v. Adams, 345 U.S. 461, 477 (1953).

24. Jackson v. Metro. Edison Co., 419 U.S. 345, 358 (1974).

25. Moose Lodge No. 107 v. Irvis, 407 U.S. 163, 177 (1972).

26. Flagg Bros. v. Brooks, 436 U.S. 149, 166 (1978).

27. Hudgens v. Nat'l Labor Relations Bd., 424 U.S. 507, 518 (1976) (announcing that "the rationale of [Amalgamated Food Employees Union Local 590 v. Logan Valley Plaza, Inc., 391 U.S. 308 (1968)]," in which the Court found that a shopping mall engaged in state action, "did not survive ... [Lloyd Corp. v. Tanner, 407 U.S. 551 (1972)]").

28. Flagg Bros., 436 U.S. at 159-60; Jackson, 419 U.S. at 350-51.

29. Shelley v. Kraemer, 334 U.S. 1, 19-23 (1948).

30. Marsh v. Alabama, 326 U.S. 501, 507-08 (1946).

31. Id. at 505-09.

32. Jackson v. Metro. Edison Co., 419 U.S. 345, 351 (1974). 
doctrinal statement or even a loose theory concerning how these facts should be evaluated and weighed against one another.

In Marsh v. Alabama, the company-town case, the Court declared that " $[\mathrm{t}]$ he more an owner, for his advantage, opens up his property for use by the public in general, the more do his rights become circumscribed by the statutory and constitutional rights of those who use it." 33 This has surely been a justification for antidiscrimination statutes applicable to places of public accommodation, ${ }^{34}$ but as a statement concerning the application of public Constitutional Law it is woefully incomplete. No court has found that a business is a state actor bound to respect "constitutional rights" merely because it has opened itself to the public in general. ${ }^{35}$ This factor alone cannot explain, if it can be explained, how it could be thought that Marsh is correct but that its reasoning should not extend to other businesses. ${ }^{36}$

An extensive record of scholarship exists on this sort of state action question. While each theoretical approach uncovers important truths, each is found wanting by proving too much, standing for too little, appearing to state a test but ultimately passing the untransformed question to courts, or otherwise failing to grapple with what is actually difficult in these cases. Our intuition is onto something, but the theories do not fully follow it.

In broad, taxonomic outline, they concern ad hoc factors, a balance of the competing rights of the plaintiff and defendant, the degree of an actor's power in the market, or the actor's formal public or private status. Part III will explore these in more detail and contrast their

33. Marsh, 326 U.S. at 506.

34. See, e.g., Mark Kelman, Market Discrimination and Groups, 53 StAN. L. Rev. 833, 854-55 (2001) (arguing that when an accommodation is open to the public, a desire to discriminate is economically irrational and can only be motivated by "illegitimate" private desires the state should "destroy").

35. See, e.g., Brooks v. Chicago Downs Ass'n, 791 F.2d 512, 515-19 (7th Cir. 1986) (approving private exclusion for any reasons other than those prohibited by statute).

36. The Court's further observation that " $[\mathrm{w}]$ hether a corporation or a municipality owns or possesses the town the public in either case has an identical interest in the functioning of the community in such manner that the channels of communication remain free" is on its face unhelpful. Marsh, 326 U.S. at 507. Read too coarsely, it suggests a sort of durability of individual, constitutional rights and the need to protect them regardless of whether the threat is governmental or private. Rights are rights, and contra Hohfeld, they are inherent rather than relational. Wesley Newcomb Hohfeld, Some Fundamental Legal Conceptions as Applied in Judicial Reasoning, 23 YALE L.J. 16, 30-32 (1913) (arguing that a "right" necessarily refers to a correlative "duty"). But there is more than a hint of a far better and more interesting idea here. The problem the Court identifies is not the mere blocking of an individual's speech by a private entity, but the blocking of whole "channels," disrupting the "functioning of the community." Marsh, 326 U.S. at 507. This approach, as will be shown, is consistent with the doctrinal test derived from the institutional theory I develop in this Article. 
application with that of the institutional theory I develop next. But a brief description of these approaches will help to show why the move to institutional analysis is promising.

Ad hoc tests based on arrays of factors suffer from the familiar problems of multifactor balancing tests. Such tests may provide some degree of guidance by at least excluding some issues from consideration, but, ultimately, they delegate to courts the relatively unmodified question of whether an actor is "state-like" or sufficiently connected to the state.

Subtly different from the ad hoc approach are those theories that advocate junking or substantially limiting the state action doctrine and instead balancing the constitutionally relevant interests of each side of the dispute, with perhaps ancillary reliance on other policies. ${ }^{37}$ The trouble with this approach, aside from the extent of regulatory authority it delegates to courts, is that it assumes that constitutional regulation would be better but for the abrogation of individual, constitutional rights it necessarily entails. As I will argue, this approach takes inadequate account of the fact that Constitutional Law is tailored to the institutions it governs. ${ }^{38}$ A private actor may be poorly governed by constitutional rules, not only because such rules would abrogate the actor's own constitutional rights, but also because private actors are not the types of entities constitutional rules are designed to govern.

An actor's power in the market provides a seemingly better justification for finding state action. ${ }^{39}$ Under this kind of approach, state

37. See, e.g., Erwin Chemerinsky, Rethinking State Action, 80 Nw. U. L. Rev. 503 (1985) (arguing that the state action doctrine should be eliminated and replaced by a balancing test in which courts would weigh the right infringed against the justification for the infringing activity); Louis Henkin, Shelley v. Kraemer: Notes for a Revised Opinion, 110 U. PA. L. REV. 473, 481 (1962) (arguing for state action when the state could have proscribed the private denial of constitutional rights if so finding is not outweighed by the actor's liberty and property rights); William W. Van Alstyne \& Kenneth L. Karst, State Action, 53 StAn. L. Rev. 3 (1961) (arguing for examining the effects on the interests and on local authority of the parties of federal intervention); see also Larry Alexander, The Public/Private Distinction and Constitutional Limits on Private Power, 10 Const. COMmENT. 361, 372 (1993) (setting forth a three-question state action inquiry, centering on whether the private rights violation has similar effects as state denial would and, if so, whether the justifications for upholding private denial are substantially weightier than those for upholding state denial would be).

38. See infra Subsection III.A.3.

39. See, e.g., Adolf A. Berle, Jr., Constitutional Limitations on Corporate ActivityProtection of Personal Rights From Invasion Through Economic Power, 100 U. PA. L. Rev. 933 (1952) (examining the theory that large corporations, because they are creatures of the state and exert great economic control over the citizenry, should be subject to constitutional restraints); Jesse H. Choper, Commentary, Thoughts on State Action: The "Government Function" and "Power Theory” Approaches, 1979 WASH. U. L. Q. 757 (1979) (endorsing a finding of state action when private parties exercise governmental power); Ralph K. Winter, Jr., Changing 
action exists if a private actor wields substantial market power, perhaps literally monopolistic. But what kind of power matters, and why? Why should relative wealth trigger regulation by constitutional regulations meant to govern the state? To the extent that market power is a proxy for finding coercive capacity, the theory looks in the right place. As I will argue, however, power alone is a descriptively and normatively inadequate basis for finding state action. ${ }^{40}$ It is manifestly not the case that powerful private actors are considered state actors under the Supreme Court's doctrine. More critically, I will argue that looking only to private power fails to grapple with both the suitability of public Constitutional Law as a means of regulation, and the capacity of courts to apply it or its principles wisely in such cases.

The formal-identification approach urges that the state action label be reserved for formal, government officials. ${ }^{41}$ There is an important intuition in this very rule-like approach, which suggests the inappropriateness of the application of the rules of government to private parties and which is perhaps also skeptical of courts' abilities to apply such rules to private parties. It would not, however, be able to sustain the results in a number of existing cases, including Shelley.

Which of these approaches should be used? What really matters? Is it the importance of the individual rights, the power of the private actor, or the individual rights of the private actor or his or her opponents? Is it a balance of all of these? Or is it only the actor's formal status, the actor's resemblance to a recognizable form of state agency, or the resemblance of the actor's particular conduct to typical governmental conduct? The cases do not tell us. The theorists disagree, and there does not seem to be a good way to evaluate the competing arguments.

As I will explain, the root of the problem is that the Court and most scholars have shoehorned what should be a two-step inquiry about the nature of institutions (namely, the private actor and the Court itself) into a single, purportedly substantive inquiry into the "nexus" between the private actor and the state, even for state action cases that are not "find the state" cases. ${ }^{42}$ It doesn't work. To see why, and to focus the doctrine

Concepts of Equality: From Equality Before the Law to the Welfare State, 1979 WASH U. L. Q. 741, 744 (1979) (arguing for state action, inter alia, where a private exercise of power is literally monopolistic, like government action).

40. See infra notes 115-20 and accompanying text.

41. See, e.g., Richard S. Kay, The State Action Doctrine, the Public-Private Distinction, and the Independence of Constitutional Law, 10 Const. CommenT. 329, 333-34 (1993) (arguing for limiting the doctrine to sanctioned acts of government officials).

42. See Dilan A. Esper, Note, Some Thoughts on the Puzzle of State Action, 68 S. CAL. L. REV. 663, 682-87 (1995) (describing the nexus "theory" of state action). 
on the right questions, we must first understand the public-private institutional structure that all legal systems share.

\section{The Institutional TheORY of StAte Action: An Alternative APPROACH}

Beneath a jumbled surface teeming with doctrines, principles, rules, and exceptions, legal systems are built on a bedrock of simple distinctions between what is public and what is private. Basic to collective governance are decisions concerning what institutions should exercise what kinds of legal authority. And the primary choice of institution is that between a public actor on the one hand and a private actor on the other. ${ }^{43}$

This underlying public-private structure of legal systems is usually not apparent in practice. The focus in most legal disputes is on subjectspecific doctrine, but this specificity is often illusory. What looks like a doctrine peculiar to an area of contract law, for example, can instead be understood as the consequence of applying a much more general principle to that area's particular institutional context. While there is much to be gained from understanding these trans-substantive principles, legal disputes are almost always resolved without acknowledging them directly.

The state action cases lie in that area of our law where the publicprivate distinction - and thus an inevitable grappling with basic principles - comes to the surface. These cases are outcroppings of law's public-private bedrock, exposing the normally hidden complexity of the boundaries. By studying them, we learn more about law's underlying structure. And more importantly, by understanding the bedrock, we can finally make sense of these seemingly mysterious outcroppings.

In this Part, I will begin by describing law's public-private structure and explaining how public and private lawmaking each are governed by specially tuned bodies of Constitutional Law intended to solve the predictable institutional problems of these very different lawmakers. Then, I will turn to an institutional theory of state action in legal systems. A firm understanding of the public-private structure will render obvious the two-part inquiry at the heart of our own state action doctrine: identification of state action problems followed by an analysis of the need for and ability of courts to solve them.

\section{A. The Bedrock}

Legal systems are structured at their basic level by divisions of authority between public and private decision makers. It is intuitive,

43. See generally Turner, supra note 7. 
after all, that among any collective's initial and most important projects is to define those things it will do collectively and those it will leave to its individual members. ${ }^{44}$ With respect to its legal system, the rules under which the collective will use its coercive power can be collectively (publicly) or individually (privately) made. Putative violations can be publicly or privately prosecuted. This basic division of authority defines our most fundamental legal categories. ${ }^{45}$ Privately made and privately prosecuted law, I call Contract Law. Publicly made and privately prosecuted law, I call Tort Law. Publicly made and publicly prosecuted law, I call Criminal Law. And, privately made and publicly prosecuted law, I call Parens Patriae. These categories are summarized in the following chart:

\begin{tabular}{|c|c|c|}
\cline { 2 - 3 } \multicolumn{1}{c|}{} & $\begin{array}{c}\text { Privately } \\
\text { Created }\end{array}$ & $\begin{array}{c}\text { Publicly } \\
\text { Created }\end{array}$ \\
\hline $\begin{array}{c}\text { Privately } \\
\text { Prosecuted }\end{array}$ & Contract Law & Tort Law \\
\hline $\begin{array}{c}\text { Publicly } \\
\text { Prosecuted }\end{array}$ & Parens Patriae & Criminal Law \\
\hline
\end{tabular}

The power of this taxonomy of legal systems arises from its characterization of substantive law in terms of institutional control. The public and the private are the highest-level institutions within any collective. Each will invariably contain numerous subdivisions (legislatures and courts, for example, on the public side, corporations and families, for example, on the private side), but these subinstitutions inherit many features of, and legal rules applicable to, the parent institutional category. By creating a substantive map of legal systems in terms of institutional control over basic decisions, we can (1) understand apparently substantive problems in institutional terms and (2) translate problems and results from one substantive area of law to another by noting and adjusting for the different institutional environments.

But how do we decide who makes and prosecutes which kinds of law and under what constraints? That is, how do we populate the taxonomy's boxes? Legal systems have "metalaw" to answer these questions about their laws. I call the metalaw governing the making of law "Constitutional Law" and the metalaw governing the prosecution of

44. Id. at $1009 \&$ n. 15 .

45. Id. at 1010-13. 
law violations "Procedure." 46 Thus, the basic public-private structure of legal systems is summarized in this chart.

\begin{tabular}{|c|c|c|c|}
\hline & \multicolumn{2}{|c|}{ Constitutional Law } \\
\hline & & $\begin{array}{l}\text { Privately } \\
\text { Created }\end{array}$ & $\begin{array}{l}\text { Publicly } \\
\text { Created } \\
\end{array}$ \\
\hline \multirow{2}{*}{ Procedure } & $\begin{array}{c}\text { Privately } \\
\text { Prosecuted }\end{array}$ & Contract Law & Tort Law \\
\hline & $\begin{array}{c}\text { Publicly } \\
\text { Prosecuted }\end{array}$ & Parens Patriae & Criminal Law \\
\hline
\end{tabular}

Legal systems therefore possess a body of private Constitutional Law and a body of public Constitutional Law. Their differences reflect the institutional contrasts between the lawmakers in each category. What is usually called "contract law" (including the rules of offer and acceptance and other criteria for contract validity, the rules governing contract interpretation and construction, and the rules concerning the making and enforcement of contracts) is, in fact, the "Constitutional Law of Contracts." Contract law itself is the body of substantive law specified by the many individual terms arising out of the universe of privately created contracts.

While all Constitutional Law, public and private, concerns the rules for selecting lawmakers, determining the scope of their powers, and the measurement of enactments for compliance with various policiesstructure and rights in the usual parlance-these rules are quite different in Contract than in Tort and Criminal Law. The taxonomy helps us to appreciate that these rules differ precisely because they apply in different institutional contexts. Because private and public lawmakers have different stereotypical strengths and weaknesses, the metalaw governing their lawmaking decisions will differ in response to these characteristics.

So, for example, Contract's lawmakers are determined by a few rules (for example, age and other capacity rules) but primarily by standards meant to establish the consent of the parties who would be bound. ${ }^{47}$ If a proposed law has the consent of all the parties who might be obligated under it, then that law is, as an ex ante matter, appropriately enacted by the consenting parties. That is, we vest private parties with lawmaking power over laws that will bind only them.

46. Id. at 1013.

47. Id. at 1035-38; see also, e.g., Joshua Fairfield, The Cost of Consent: Optimal Standardization in the Law of Contract, 58 EMORY L.J. 1401, 1403 (2009) ("In contract theory, consent is indispensable....”). 
Contrast this with publicly made laws, where lawmakers are chosen by rule-like procedures, normally by popular voting or appointment by other public officials, and given the authority to make laws of certain types regardless of the consent of the individuals who will be bound as a result. ${ }^{48}$ Public lawmakers are empowered to make laws that will bind others. Because of this, the rules for public lawmaker selection and legislative scope are tuned to control the deficiencies private individuals might normally have when making laws that will apply to others.

Even if private and public lawmakers are vested with authority, their output might prove contrary to the public good. While they appeared appropriately positioned to make law as an ex ante matter, reading the law ex post it may become clear that the institution failed to perform as designed. Contracts, though apparently voluntary, may be unconscionable or contrary to public policy. ${ }^{49}$ Public laws, though validly enacted, may violate important rights (which I will, for convenience, refer to under the umbrella term "due process"). ${ }^{50}$

Constitutional Law meant to detect these sorts of problems with legislative output is of a different type than that which governs lawmaker selection ex ante. I have identified two abstract, institutionally grounded principles from which these two branches of Constitutional Law can be derived. ${ }^{51}$

I have labeled the "first principle," or ex ante principle, the imperative that decision makers be selected and empowered in a way that is likely to render them institutionally competent. This means that they are likely to act consistently with an attempt at some optimization of a social welfare function. ${ }^{52}$ Deconstructing an arbitrary function into the capacities needed appropriately to perform it, I have identified five discrete, core competencies: private calculation, public calculation, aggregation, distribution, and resource. ${ }^{53}$ These five points of institutional comparison give us a somewhat crude but at least analytical method of evaluation, an institutional calculus.

48. Turner, supra note 7 , at $1038-42$.

49. See, e.g., U.C.C. § 2-302(1) (2011) ("If the court as a matter of law finds the contract or any clause of the contract to have been unconscionable at the time it was made the court may refuse to enforce the contract...."); RESTATEMENT (SECOND) OF CONTRACTS $\S 178$ (1981) (explaining when a contract is void as contrary to public policy).

50. See, e.g., Brown v. Mississippi, 297 U.S. 278, 285 (1936) (noting that due process protects "principle[s] of justice so rooted in the traditions and conscience of our people as to be ranked as fundamental" (citation and internal quotation marks omitted)).

51. See Turner, supra note 7, at 1033-34.

52. I do not assume any particular function.

53. See Turner, supra note 7, at 1018-20. 
- Private calculation competency reflects the ability of an institution to estimate the preferences of others with respect to the decision at hand. An individual is often, but not always, the best calculator of his own preferences and therefore usually has a private calculation advantage over others with respect to decisions that affect only him. ${ }^{54}$

- Public calculation competency refers to the ability to assess that portion, if any, of the collective good not reflected in individual preferences. ${ }^{55}$ If such public preferences exist, private institutions are often, but not always, relatively less competent to assess them than appropriately constituted public entities.

- Aggregation competency is the ability of a decision-making entity to combine these preference inputs, weighing and ordering them according to the collective will. ${ }^{56}$

- A particular kind of aggregation competency is the ability to weigh the preferences of another as heavily as one's own. I call this capacity to decide unselfishly distributive competency. ${ }^{57}$

- And finally, resource competency is the possession of the means actually to effect a decision. ${ }^{58}$

Any two institutions, and in particular a public and a private entity, can be compared by their relative advantages in these core competencies. My first principle demands that lawmakers be selected and empowered in such a way that the resulting lawmaking body will possess all of these competencies. ${ }^{59}$ This institutionally posed principle yields substantive legal rules when reduced to application in a specific institutional context.

The first principle applied to private lawmaking leads to a rule that a contract must have the consent of all those who would be bound by its terms. Private individuals are stereotypically well-positioned to take account of their own preferences. ${ }^{60}$ While they are sometimes able to calculate the preferences of other individuals, it would be problematic to

54. Id. at 1019.

55. Id.

56. Id.

57. $I d$.

58. Id. at 1020.

59. Id. at 1034-42.

60. See, e.g., Frank H. Knight, Risk, Uncertainty and Profit 77 (1921) ("Every person is the final and absolute judge of his own welfare and interests."); Turner, supra note 7, at 1019 . 
permit an individual to make law for another outside of narrow circumstances. ${ }^{61}$ This may be due in part to a misapprehension of the other's preferences, but it is certainly the case that individuals almost always weigh their own preferences more heavily than those of others. The tendency toward distributive disadvantage is so severe in individual private lawmakers that societies generally bar them from making laws that bind non-consenting others. ${ }^{62}$

Private groups of individuals, however, can solve this problem through agreement. By manifesting agreement to be bound, a private group can signal that it is, collectively, distributively competent and well-calculating. ${ }^{63}$ If the group believes it will be better off with a law applicable only to itself, many societies will enforce the law, believing that individuals know themselves best and that society is better off when its members are better off. As an ex ante matter, before the content of its law is examined, a consenting group of lawmakers proposing to bind only itself has all the core competencies and satisfies the first principle. $^{64}$

Contrast this with public lawmaking bodies, those invested with the necessary but hazardous responsibility of making law that will bind others involuntarily. These bodies must be chosen in a way that maximizes their potential to take account of others' preferences (private calculation competency) and, most critically, minimizes the risk that lawmaking authority will be used for private gain or for the enrichment of some groups at the expense of others contrary to the collective will (distributive and aggregative competency). Selection mechanisms, which often seem to be rule-like and formal, and lawmaking procedures are tuned to ensuring good agency. ${ }^{65}$ Private contracting groups, by contrast, are not bound by rules that condition their authority on being good agents of non-members, because they, unlike public lawmaking bodies, are rarely empowered to make laws binding non-members.

61. Such circumstances include the parent-child relationship and guardianships. See, e.g., Prince v. Massachusetts, 321 U.S. 158, 166 (1944) ("It is cardinal with us that the custody, care and nurture of the child reside first in the parents, whose primary function and freedom include preparation for obligations the state can neither supply nor hinder."); W.J. Dunn, Annotation, Mental Condition Which Will Justify the Appointment of Guardian, Committee, or Conservator of the Estate for an Incompetent or Spendthrift, 9 A.L.R.3D 774, § 2[a] (1961) ("[I]t now seems to be well settled that the courts may appoint a guardian, conservator, or committee to manage the property or estate of another, without a finding that the ward is generally or totally insane.").

62. See Turner, supra note 7, at 1022-23.

63. Id. at 1022 .

64. Id. at 1035-36.

65. See id. at 1039-40 (citing and discussing Adrian Vermeule, The Constitutional Law of Congressional Procedure, 71 U. CHI. L. REV. 361 (2004)). 
The "second principle," or ex post principle, examines decisionmaking output for manifest institutional failure. ${ }^{66}$ Such failures occur when a lawmaking body, despite compliance with the first principle, nonetheless generates a law demonstrating that it lacks the core competencies. Even though the first principle may have been satisfied, a law's content can reveal, ex post, a lawmaker's core incompetence. In the private context, unconscionability is, at bottom, a doctrine derived from the second principle. It is an inquiry into whether an apparently voluntary - and thus first-principle compliant-agreement is so unfair that it manifests substantial private-calculation failure (ignorance) or distributive failure (coercion). ${ }^{67}$ Both are ways that, ex post, a private law's output can negate the ex ante presumption that apparent consent reflects actual voluntarism.

Further, a private law that is otherwise voluntary but is contrary to public policy is one that manifests a failure of public calculation or aggregation advantage. ${ }^{68}$ In our legal culture, voluntary assent to a private law that will bind only the contracting parties is usually assumed to be in the public interest. ${ }^{69}$ If those affected believe they will be better off with the law and if no other entities are affected, then we presume the enactment contributes to the public good. On rare occasions, however, this is not the case. Examining the contract, the output of the private lawmaking process, it may become apparent that the parties lacked public calculation or aggregation advantage; even though they were unselfish among themselves and fully took into account their compound welfare, they failed egregiously to measure the impact on total social welfare in the same way the public would. ${ }^{70}$ Their decision

66. See Turner, supra note 7, at 1042-45.

67. See, e.g., Hume v. United States, 132 U.S. 406, 410 (1889) (describing an unconscionable contract as one "no man in his senses, not under delusion, would make"); Williams v. Walker-Thomas Furniture Co., 350 F.2d 445, 449 (D.C. Cir. 1965) ("Unconscionability has generally been recognized to include an absence of meaningful choice on the part of one of the parties together with contract terms which are unreasonably favorable to the other party.").

68. See Turner, supra note 7, at 1035 n.70..

69. See, e.g., K.N. Llewellyn, Book Review, 52 Harv. L. Rev. 700, 702 (1939) (reviewing O. Prausnitz, The Standardization of COMMERCial CONTRACTS IN ENGLish AND CONTINENTAL LAW (1937)) ("Our courts are loath indeed to throw out a contract clause under the plain justification that it is contrary to public policy ....").

70. See, e.g., United States v. King, 840 F.2d 1276, 1283 (6th Cir. 1988) (“[A] parent's contract allowing a third person to burn, assault or torture his child is void.”); Dwyer v. Jung, 336 A.2d 498, 501 (N.J. Super. Ct. Ch. Div. 1975), aff'd per curiam, 348 A.2d 208 (N.J. Super. Ct. App. Div. 1975) (invalidating a restrictive covenant between lawyers because it harmed the public's "unlimited choice of counsel"); McCutcheon v. United Homes Corp., 486 P.2d 1093, 1097 (Wash. 1971) (invalidating an exculpatory clause in a landlord-tenant contract, "the generalized use of which may have an impact upon thousands of potential tenants"). 
in such a situation, therefore, does not match the reason they are, institutionally, given lawmaking power in the first place, because they have not enhanced overall social welfare through private empowerment.

In the public lawmaking context, the various due process rights serve the ex post examination function that unconscionability and public policy limits provide in private contracting. ${ }^{71}$ Assuring voluntarism of all those affected is no longer the institutional strategy. Unlike private contracting parties, public lawmakers are agents. The first principle yields specific constitutional efforts to secure good lawmaking agents, including rules concerning representative selection schemes and public visibility intended to promote accountability, but these are no guarantee. $^{72}$ Like any agents, public lawmakers may miscalculate the principal's wants or even substitute their own wants for the principal's. For this reason, public Constitutional Law is concerned with encouraging good agency, choosing and structuring agents in such a way that they are more likely to take proper account of individual welfare and to act unselfishly and policing lawmaking output for manifest institutional failure. For example, a public law that pursued private redistributive efforts, in contravention of the public good, would run afoul of the second principle. ${ }^{73}$

Because public Constitutional Law polices agent behavior rather than consent, it often authorizes more searching review of lawmaking output under the second principle than private Constitutional Law does. While it is possible that apparent consent in Contract Law hides coercion, there is probably a far greater danger that public lawmaking agents may abuse their status to pursue nonpublic ends. And while it is possible that contracting parties, even those creating obligations only among themselves, may try to enact laws that conflict with public norms or have adverse social effects beyond the parties, there is, here too, a far greater danger that public laws binding broad swaths of society will be inimical to social values. Our own law reflects these concerns, subjecting publicly made law to more numerous and comprehensive prohibitions and to greater judicial scrutiny than privately made law. In what follows, we will explore just how much more control courts have over the substance of public laws.

This difference in treatment under the second principle means that much turns on the characterization of law as publicly or privately made.

71. See Turner, supra note 7, at 1043-45.

72. Id.; see also Vermeule, supra note 65, at 381-82.

73. See Turner, supra note 7, at 1039; see also Kelo v. City of New London, 545 U.S. 469, 493 (2005) (Kennedy, J., concurring) ("There may be private transfers in which the risk of undetected impermissible favoritism of private parties is so acute that a presumption (rebuttable or otherwise) of invalidity is warranted under the Public Use Clause.”). 
I call this sort of problem, where the metalegal treatment of an institution's output depends on the characterization of an institution, a Categorization Problem. Such a problem, as noted above, lies at the root of our difficulty with the state action doctrine. So let us turn now to the Categorization Problem arising from the distinction with which the doctrine grapples - that between public and private lawmaking.

\section{B. The Outcropping}

The public-private structure of legal systems suggests that the private creation and private enforcement of law will be regulated differently, owing to the private character of the lawmakers and prosecutor, than will be the public creation and public enforcement of law. The public and private are fundamentally different institutional types, prone to different kinds of deviations from the public interest, and thus their decisions are subjected to different forms of scrutiny. But how do we tell in a given case whether the decision-making entity is public or private?

In most legal systems, the question whether an act of lawmaking was public or private is almost always resolved without any conscious effort. Nearly all lawmaking is, under the system's rules, clearly public or clearly private. This is not to say that there is uniform agreement, as a theoretical matter, to the public or private nature of the dispute in total. Rather, by this I mean that there is usually no argument made concerning the appropriate body of Constitutional Law that should apply: All parties agree to apply either public or private Constitutional Law without even thinking to disagree. The bedrock, shaped by a set of

public-private distinctions, is stable and essentially forgotten despite the fact that so much turns on it. ${ }^{74}$

When the bedrock outcrops, however, revealing that the public or private nature of the lawmaker presents an unresolved Categorization Problem, a great deal of theoretical confusion ensues. In the United States, we do little more than muddle through such situations, and the resulting cases are criticized as unprincipled and chaotic. These cases, nonetheless, have established a state action doctrine that is mostly on

74. To be sure, one could design a legal system in which this stability and invisibility are absent. Suppose that acts of public lawmaking were identified not by detailed rules identifying public agents but by a standard that measured the "public impact" of an otherwise private act, together with various other criteria. If met, the act would be privileged as law binding on those having nothing to do with the act. It is not difficult to anticipate contests over the application of this judicially-managed standard in nearly every case of private lawmaking. There are reasons based in the first principle to think that legal systems are unlikely to depart much from clear rules to identify public lawmaking agents. But I do not claim that the public-private distinction is necessarily a hidden fault line in all legal systems. 
sound theoretical footing. The public-private structure theory, casting state action cases as problems of selecting between public and private Constitutional Law, allows us to see why this is so.

I begin this section by demonstrating how the public-private structure theory focuses the state action analysis on the right problem, that of the selection of secondary rules. I then develop a two-part, institutional test that judges should use to decide whether there is state action justifying application of public constitutional principles to private activity. In the first part of the test, we ask whether there is a state action problem, meaning a mismatch between the private lawmaking at issue and the private Constitutional Law meant to govern it. In the second, we ask whether courts are the appropriate body to supply a solution to the mismatch.

\section{The Nature of the Public-Private Inquiry}

The difficulty posed by state action cases begins to resolve as soon as one understands the problem as primarily one of selection between different bodies of governing Constitutional Law, each designed to govern a different institutional type. Our legal system cannot avoid performing this selection. The question is how, not whether, it should be done.

Some state action theories deny that there is a coherent and desirable selection method but instead argue that courts should have ad hoc authority in exceptional cases to govern private actors as though they were public. ${ }^{75}$ Such theories often attack the coherency of the publicprivate distinction, noting, for example, that every time the collective enforces a private contract, there is public action. ${ }^{76}$ By denying the existence of a truly private sphere that ought to be immune from public Constitutional Law, this approach would give courts the power to perform the selection on a case-by-case basis, in each instance asking directly which body of metalaw would yield the better result. If no dispute settled by collective coercion is ever purely private, and if any public involvement is sufficient to give courts the power to import public Constitutional Law principles, then, indeed, there are only state action cases, not state action principles.

75. See, e.g., Chemerinsky, supra note 37, at 551 (proposing that courts discard the state action doctrine and instead "balance the rights of the violator and victim" and apply the Constitution whenever "a person's rights were unjustifiably infringed," no matter the public or private status of the infringer).

76. Id. at 525-26; see also Shelley v. Kraemer, 334 U.S. 1, 20 ("[I]n granting judicial enforcement of the restrictive agreements in these cases, the States have denied petitioners the equal protection of the laws ....”). 
This nihilistic denial of the possibility of distinguishing public and private leads us down the wrong path. It mistakes a tractable but multidimensional problem for an indeterminate, single dimensional one. It sees an undifferentiated mass of metal where the trained and careful eye would see separate but cooperating components of an engine. The key is this: If we are careful to avoid the trap of describing law or some practice as public or private in general and instead focus on whether a public or a private entity is the source of a particular decision, much of the perceived incoherency of the distinction falls away.

For example, the substance of a private contract is created not by the collective but according to private will. The public will choose to back such private legislation with public coercion if certain publicly imposed conditions, those of private Constitutional Law, are met. ${ }^{77}$ Thus, concededly, law's product, the ultimate decision whether to use collective coercive capacities (such as fines, damages, injunctions, or imprisonment), is indeterminately public or private. It is both. But it is a composition of separate public and private decisions. Decomposing that product into the antecedent decisions leading to it resolves much of the indeterminacy and permits analysis of the rules governing those separate exercises of public and private power that combine to yield a judgment.

For this reason, observing, as Shelley did, that the public is "involved" in enforcing a privately made law is not an appealing ground for applying public Constitutional Law. Advocates of finding state action on this basis justify using public constitutional rules meant to govern the making of one decision (what the content of a law should be) because the public was involved in a different decision (whether and how to coerce compliance). But private constitutional rules are tuned to protect the public interest when private parties make law. There is no justification to use rules meant to govern the public creation of law on account of the public's involvement in enforcing law that is already made. $^{78}$

77. As with publicly made legislation, private legislation is often the subject of interpretation. The fact that courts will sometimes decide between competing meanings of privately drafted text does not alter the fact that the source of the text was a private entity, acting according to a private will. In this sense, the criticism that courts - through interpretationrender supposedly private legislation public recapitulates the debate over the judicial role in interpreting public legislation.

78. Obviously, constitutional rules applicable to enforcement, which ought to be calibrated to protect against institutional failures likely to arise from public enforcement, would apply to the activity of enforcement. The point here is that public constitutional rules applicable to lawmaking are not suited to govern private lawmaking, given the different institutional characteristics of private lawmakers. So if we are to apply public constitutional rules to the act of private lawmaking, there must be some other reason to do so than public enforcement. 
Is there, then, ever a reason to apply public Constitutional Law to private-law creation? The answer lies in asking the right question: not whether there is some sufficient quantum of public involvement, but whether a particular act of private lawmaking is adequately governed by private Constitutional Law.

Private Constitutional Law is particularized in a legal system by rules guarding against the stereotypical problems of private lawmaking. Public Constitutional Law is a set of specifications and constraints designed to avert the stereotypical problems of public lawmaking. The state action dilemma arises when we are unsure which body of Constitutional Law to apply. The institutional state action doctrine I propose here is a functional response to this instance of the Categorization Problem, one that aims to pair acts of lawmaking with the type of Constitutional Law that is most appropriate for the lawmaking institution at issue. Deciding whether there is state action is, at bottom, a problem of matching law with an institutionally tuned, governing metalaw. The work of the theory lies in describing the institutional parameters that should be used to make this selection.

Since my focus is on the application of such an institutional state action theory in U.S. law, which divides regulatory power amongst multiple, public institutions, we must address an additional question: How should responsibility for solving this Categorization Problem be allocated to different public institutions? A primary contribution of my approach is that it makes clear that state action cases involve two very different, but still inherently institutional questions: (1) whether the private lawmaking actor is poorly governed by ordinary private Constitutional Law and (2) whether courts should remedy a mismatch or leave the problem to other public institutions.

\section{The First Step: State Action Problems}

A state action problem, as I define the term, arises when the secondary rules governing an apparently private decision maker are a poor fit because the decision maker's potential institutional defects more closely resemble those of public entities than those of private ones. I will not attempt to characterize all the circumstances in which state action problems, so defined, might arise. Rather, I will focus on what I suspect is their overwhelmingly dominant source: private rules that have coercive effects on non-consenting others.

Private lawmaking is generally premised on the existence of an agreement among a group of private lawmakers who will be the only ones governed by the law they make. It is universal consent that vitiates the ordinary distributive and calculation incompetencies of private 
parties. ${ }^{79}$ In societies that place great value on individual welfare, like ours, a privately made law accords with the preferences of the collective because it is desired by all those who will be obligated by it and places obligations on no one else. Put differently, self-interested, private legislation aligns with the collective good when and only when it has the consent of all those with significant interests in it.

In contrast, public lawmaking is a collective's mechanism for creating rules that govern its members without obtaining unanimous consent. Self-interested lawmakers are anathema to this process, as they may make laws disproportionately serving their own interests and with poor understanding of the interests of others. A primary concern of the second principle in public Constitutional Law is to scrutinize legislative output that is likely infected with these incompetencies, despite firstprinciple-based efforts to constitute legislatures to avoid such problems. Laws burdening groups and movements with little political representation are perfect examples of targets for second-principle scrutiny, as electoral incentives may not adequately stand in for truly internalizing the preferences of such groups. ${ }^{80}$

Given the divergent concerns and methods of private and public Constitutional Law, we should expect legal systems to have a hard time handling privately made laws that, on the one hand, comply with the formal enactment procedures for private law (valid contracts, for example), and yet, on the other hand, impose burdens on nonparties without their consent. The former aspect of such laws argues for application of private Constitutional Law, but the latter aspect justifies resort to public Constitutional Law. This is the Categorization Problem lurking behind the state action doctrine.

The heart of the difficulty is that Constitutional Law is specifically adapted to the very different sources of institutional failure arising in private and public lawmaking institutions. Applying private secondary rules to a lawmaking institution that is more prone to the defects of public institutions would be a mistake at the legal system's very core, like using a recipe to make bread but with the ingredients to make a salad. Inappropriate categorization frustrates the primary purpose of the system's secondary rules: to help ensure an institution's decisions are competent as measured against public norms.

79. See supra notes 47-48 and accompanying text.

80. See, e.g., John Hart Ely, Democracy AND Distrust: A Theory of Judicial REVIEw 76-77 (1980). Again, the claim is not that all such laws are in fact the product of incompetent lawmakers. But laws that place special burdens on those who are poorly represented do pose that danger, sufficiently so that more careful scrutiny of whether competent lawmaking could produce such a law is warranted. 
It may help to restate the functional, institutional criterion in doctrinally oriented terms. Private action that amounts to public legislation creates a state action problem. When private individuals make law for others, it becomes relevant whether they have acted adequately on those others' behalf, just as it is relevant for public legislatures. The consent among the enactors is a poor proxy for the overall public impact of the law. If we choose to allow such lawmaking at all (and our legal system sometimes does), the controls of public Constitutional Law are a much better fit for ex post, second principle review.

I say these sorts of laws raise state action "problems" because simple application of ordinary private Constitutional Law would poorly govern the lawmaker. It is a description of the law, in negative terms, but not in itself an answer to what should be done. The work of this first step of the institutional state action doctrine is both to flag instances of private lawmaking for the second step and to signal to other public institutions the need for importing, if possible, supplementary public Constitutional Law rules into the secondary law governing the problematic category of cases. After all, the private constitutional rules were not designed to guard, as public metalaw is, against poor agency and self-interested redistribution. The dangers of poor private calculation and distributive disadvantage are typically averted by those first-principle rules in private Constitutional Law requiring voluntarism among the parties. When applied to private Constitutional Law, the second principle, which examines legislative outputs (the contracts or other private rules themselves), yields only the loose, highly deferential constraints of unconscionability and public policy. ${ }^{81}$ The first step of the analysis tells us that more is needed.

Somewhat curiously, the sprawling state action literature is mostly barren of what seems to be an intuitive and attractive formulation of state action: that it exists when private citizens legislate for others. While none provides a detailed, institutional justification for such a rule, a few articles have gestured in this direction. In an excellent student note, Dilan Esper, after finding existing theories wanting for reasons I mostly share, indicated a possible "collective action" rationale for finding state action. ${ }^{82}$ As Esper put it, Shelley might be justified by an argument that "a town cannot do through collective private action what it is disallowed to do publicly. Thus, since zoning by race is

81. As we will see in Part III, these highly deferential forms of ex post review are nonetheless sufficiently malleable to permit courts to solve state action problems without resorting explicitly to public constitutional doctrines.

82. Esper, supra note 42 , at 677-708, 715. 
unconstitutional, a system of enforceable covenants that segregate neighborhoods is also impermissible." ${ }^{\prime 3}$

This position comes closer than most to the institutional theory advanced here. Yet, it lacks the critical second step of the analysis to which I will turn next. Moreover, it is not much more than a brief animation of an intuition, albeit a correct intuition that embeds further assumptions about institutions, assumptions I have endeavored to make more explicit. But Esper's suggestion at least focuses on the right initial question: Are private individuals acting collectively to bind nonconsenting others? This is, again, a doctrinal statement that can be derived as a consequence of a more fundamental commitment. That commitment is to proper governance by secondary law when that law is generally tailored to the stereotypical attributes of the institutions to which it applies.

Carol Rose also has entertained the private takeover of legislative capacity as a possible ground for state action in her analysis of Shelley. "Widespreadness and inescapability-these were the aspects of [racially restrictive covenants] that made them seem so much like a private takeover of governmental functions; it was a takeover in which ostensibly private persons used the courts seriously to disadvantage racial minorities." ${ }^{, 85}$ Indeed, this captures a key circumstance in which the institutional criterion of the first step will be met. When exit is extremely difficult and the need is great, private providers will have substantial coercive capacity, and the rules they make tend toward legislation.

In the next Part, I will apply both steps of the institutional theory to actual cases, and I will compare the answers given by the theory to those given by other approaches. But first, let us briefly consider a couple of examples of private laws (Contract Law within the publicprivate theory) that raise state action problems, often without generating state action cases.

\section{a. Covenants}

Covenants are an odd species of contract. They are, like ordinary contracts, agreements between parties that are binding on the parties themselves. ${ }^{86}$ But they have the special characteristic that they can also bind successors in interest of the contracting landowners, a feature known as "running with the land." ${ }^{, 87}$ Parties to a covenant that runs with

83. Id. at 715 (citation omitted).

84. Rose, supra note 3, at 171-72.

85. Id. at 195.

86. 20 AM. JuR. 2D Covenants, Etc. § 1 (2012).

87. Id. $\S 19$. I use the term "covenant" to refer to real covenants and equitable servitudes, 
the land are making law not only for themselves but also for future landowners.

This arrangement presents a state action problem for the simple reason that not all those who will be bound by the private contract are parties to it. ${ }^{88}$ It is true that future landowners consent in a fashion, as they are only bound if they take the property with notice of the covenant. ${ }^{89}$ This voluntarism is a bit illusory, however. To change the law under which they live, parties subject to a covenant must often obtain the consent of all those with a right to enforce it. ${ }^{90}$ In cases in which the original lands have been subdivided, this can present a burden difficult to surmount.

But if running with the land were impossible, it would be difficult to enter private arrangements relating to the use of land, as performance is often best rendered by the occupant, not the now-departed, original contracting party. At its core, running with the land allocates the cost of transaction to parties wishing to free themselves of a law, while not running with the land allocates it to parties wishing to continue the law.

As others have noted, ${ }^{91}$ permitting private parties to make laws governing their lands that will be binding on successors poses a host of dangers. On the one hand, binding successors is necessary to make covenants effective, but on the other, it can impose unwanted burdens on successors who desire to live on the land but not under its law.

Because there is some degree of consent by those who will be bound by covenants and because it is difficult to imagine effective law between the parties without running with the land, a case can be made for private lawmaking beyond the contracting parties. But because the law affects others, the secondary law governing such lawmaking should surely be different than ordinary private Constitutional Law, which is tuned for and assumes voluntarism.

The common law has struck upon a solution. It has incorporated into private Constitutional Law a publicly derived principle meant to measure lawmaker agency. Traditionally, covenants have been required to "touch and concern the land" in order to run. ${ }^{92}$ If the substance of the agreement does not meet this standard, no voluntary acts of the parties

agreements that, however enforced, run with the land.

88. See, e.g., Rose, supra note 3, at 195-97.

89. See 20 AM. JuR. 2D Covenants, Etc. $\$ 255$ (discussing the general requirement of notice).

90. Id. at $\S 225$.

91. See Jeffrey E. Stake, Toward an Economic Understanding of Touch and Concern, 1988 DuKE L.J. 925, 942 ("[B]ecause of the market and the players, mistakes will likely be frequent, large, and costly for the successors to undo ....").

92. See, e.g., 1 Tiffany REAL PRop. § 126 (2012). 
can otherwise create it. At its most useful, the doctrine requires that the parties have entered into the agreement because of their generic status as landowners, not as individuals. That is, a contract touches and concerns the land when it would benefit and burden any owners of the lands in question. ${ }^{93}$ This criterion is, at bottom, a test to determine whether the private lawmakers are likely good agents for those who will succeed them.

In terms of the core competencies, ${ }^{94}$ while a current landowner is not particularly likely to be a good calculator of the preferences his successor will have generally, he may be better when it comes to preferences concerning the use of the land, as to which he and the successor will be more similarly situated. In addition, it provides some comfort that when it comes to enacting land-specific obligations, the current owner will be more likely to satisfy the preferences of successors when he must shoulder the same obligations and personally suffer any diminished property value in exchange for the benefits the covenant regime provides. As to these preferences, he is reasonably likely to be a good agent, whereas we would assume no such competence in binding successors to arbitrary contractual arrangements that do not primarily concern the important asset the covenanting parties and his successors have in common.

In sum, private covenants that run with the land are instances of private laws that will bind others than the enactors, a potential state action problem. The common law has adopted a substantive requirement for validity, a second-principle-derived bit of private Constitutional Law that is modeled after the agency-policing aspect of public Constitutional Law. Recognizing that these contracts bind others, we test the legislative output for indicia of good agency-that the enactors are especially likely to be representative of their successors. And in this way this corner of Contract Law has adapted to solve a state action problem.

\section{b. Common-Interest Communities}

Consider next the case of common-interest communities, including homeowners' associations (HOAs) and condominium associations. These are governing bodies established by covenants, usually called a "declaration" in this context, in a neighborhood or condominium. ${ }^{95}$ Unlike covenants containing only substantive rights and obligations (primary rules), declarations also contain secondary rules, often

93. Id.

94. See Turner, supra note 7 and accompanying text.

95. See Restatement (Third) of Prop.: Servitudes $§ 6.2$ (2000). 
constituting a board that will have ongoing rulemaking authority. ${ }^{96}$ The contracting parties creating such an arrangement, and successors in interest, agree to be bound by future rules made by the privately established board. ${ }^{97}$

Quite obviously, board-passed rules are privately made and bind others than the enactors. We therefore should expect a state action problem, a mismatch between ordinary private Constitutional Law, which insists on and then assumes consent, and the sorts of defects that could befall the private lawmaking body. Because rules passed by the board do not require the consent of every property owner, even in the weaker sense of taking property with notice of such rules, there is a potential that self-interested lawmaking could occur and produce inefficient results.

Recognizing potential private calculation and distributive problems, states have placed restrictions on this form of private lawmaking. There are procedural restrictions, first-principle-derived rules meant to produce lawmaking entities more likely to be atomically competent. Given the similarity of the institutional problem, it should not be surprising that these rules require boards to be selected and operated somewhat like democratically elected legislatures. ${ }^{98}$ After all, these first-principle-derived rules are, in each setting, attempting to solve ex ante the agency problems inherent in making law for others.

Of more interest for the present Article, though, are the secondprinciple-derived metalaws special to these arrangements. Unlike private lawmakers entering a covenant, HOA boards offer no assurance even of initial competence. The board does not itself feel, as covenanting parties do, even all the initial effects of the laws it makes. Some of the costs of its rules will immediately be borne by others. And so, it must be a good agent not only for successors in interest but for other members of the HOA whose consent will not be required for its laws to go into effect. ${ }^{99}$ The board, therefore, is in precisely the situation of any public legislature, and we have an obvious state action problem.

96. See id. $\S 6.16$ (stating governing board's authority to exercise power to bind members).

97. See id.

98. See Gary A. Poliakoff, 1 Law of Condominium Operations $\S 1: 14$. The Restatement (Third) of Property states: "[A]n association in a common-interest community is governed by a board elected by its [memhers]. The board is entitled to exercise all powers of the community except those reserved to the members." Restatement (THIRD) OF PROP.: SERVITUDES $§ 6.16$ (2000).

99. See Restatement (Third) of Prop.: Servitudes $§ 6.14$ (2000) (explaining duties of directors and officers of common-interest communities to act in good faith, to act in compliance with law and declaration, to deal fairly, and to use ordinary care and prudence). 
The move the law has made has been to permit such private lawmaking but to subject it to second-principle analysis characteristic of public Constitutional Law. Board-passed rules are subject to judicial review for reasonableness. ${ }^{100}$ There is considerable debate as to how deferential this review should be, but it is surely more rigorous than the default private Constitutional Law standard of unconscionability. While a claim of unconscionability is likely to fail when the facts (procedural and substantive) do not cast suspicion on the voluntary nature of the contract, a claim that a board-passed rule is unreasonable goes to the substantive merits of the rule. ${ }^{101}$ In addition to general review for reasonableness, legislatures and courts have imported more specific public principles into review of board-passed rules, including prohibitions on rules limiting speech, assembly, and religion. ${ }^{102}$

As with the general case of covenants that run with the land, private laws made in common-interest communities present an obvious state action problem. Legislatures and courts have responded predictably by importing those minimal first- (ex ante, procedural) and second- (ex post, substantive) principle constraints from public Constitutional Law needed to avert it.

100. See id. § 6.7; see also, e.g., Johnson v. Hobson, 505 A.2d 1313, 1319 (D.C. 1986) (assessing the reasonableness of a rule prohibiting unit owners from parking cars without current registration); Hidden Harbour Estates, Inc. v. Norman, 309 So. 2d 180, 182 (Fla. Dist. Ct. App. 1975) (describing the test for rules adopted by condominium associations as one of reasonableness).

101. Exactly how deferential this substantive review should be is a matter of some disagreement, with some jurisdictions adopting something like the business judgment rule, which mainly looks for substance indicative of self-dealing, and others doing more aggressive cost-benefit-style second guessing. See Paula A. Franzese, Common Interest Communities: Standards of Review and Review of Standards, 3 WASH. U. J.L. \& PoL'y 663, 676-97 (2000) (discussing different levels of substantive review). The institutional theory of state action suggests that the latter might normally be the better approach, unless living within a community is a stronger than normal signal of voluntary submission to the types of rule at issue. $I$ have in mind here religious communities and perhaps others bound together by conscience more than by ordinary property preferences. See generally Eduardo M. Peñalver, Property as Entrance, 91 VA. L. REV. 1889, 1967-71 (2005).

102. See, e.g., CAL. CIV. CODE $\S 1353.6$ (West 2007) (barring, with some exceptions, common-interest developments from "prohibit[ing] posting or displaying of noncommercial signs, posters, flags, or banners”); FLA. STAT. § 718.123(1) (2010) ("No [condominium] shall unreasonably restrict any unit owner's right to peaceably assemble or right to invite public officers or candidates for public office to appear and speak in common elements, common areas, and recreational facilities.”); 765 ILL. COMP. STAT. 605/18.4(h) (2010) (“[N]o [condominium] rule or regulation may impair any rights guaranteed by the First Amendment to the Constitution of the United States ....”). 


\section{The Second Step: Judicial Intervention}

As the examples above illustrate, a circumstance that presents a problem for a legal system does not necessarily have a single solution. In fact, it may not even present a problem that must be solved. Problematic cases create tension in legal systems, exerting some pressure for a better justified doctrine. But that is a long way from saying that the legal system must respond in a particular way. The existence of a state action problem does not logically imply that courts must be free to apply public Constitutional Law to formally private lawmaking. That could be one solution, but, like other potential solutions, it carries costs. Judicial resolution must therefore be justified, not assumed as valid or appropriate.

The institutional perspective allows us to see that legal systems do in fact respond to state action problems in several ways other than through a judicially administered state action doctrine. The response to state action problems can and has come from legislatures, common law courts, states, and the federal government. ${ }^{103}$ Viewing the problem this way, it becomes clear that the application by a federal court of the state action doctrine to cure a state action problem is a last resort. The doctrine steps in to apply public constitutional rules only if all other public entities have failed to supply secondary rules responsive to the peculiar failings of the private institution in front of it, and I will argue perhaps not even then.

The state action doctrine as we know it is, therefore, a body of law intended to solve a coupled problem of institutional regulation. First, is the lawmaking at issue, though formally private, so unlike stereotypical private conduct or lawmaking that the institutional controls of ordinary, private Constitutional Law are inadequate? Second, is there a reason for courts to attempt to solve the problem by imposing the public Constitutional Law it applies to public lawmaking?

This second question is a weighty one, and it is impossible to make sense of our state action doctrine without paying careful attention to it. When should federal courts take it upon themselves to attempt to solve the constitutional mismatch by finding state action and imposing public Constitutional Law on private actors? A reasonable state action doctrine would apply public constitutional rules when (1) analysis of the first question reveals there is a state action problem and (2) endemic institutional failures prevent other public institutions from supplying more appropriate secondary rules for which public Constitutional Law is an acceptable substitute. Resort by federal courts to a meat cleaver

103. See supra Subsection II.B.2.a-b (discussing legislative and common law responses to state actionstate action problems of covenants and common-interest communities). 
when perhaps a scalpel is all that is required surely ought to be rare, and, indeed, it is.

The examples of state action problems discussed in the last Subsection demonstrate the desirability of forbearance by constitutional courts in favor of smaller-scale adjustment by other lawmaking bodies. Classes of like cases raising state action problems, such as HOA disputes, can be addressed by modestly importing only certain elements of public Constitutional Law. Where private legislation notwithstanding unavoidable state action problems is desirable and a category of such legislation is identifiable, a special class of metalaw can be developed.

The state action doctrine, though, is used to decide cases in which state action problems fall all the way through the system, unremedied by other legislative or judicial efforts. When all available metalaw has been exhausted but still found wanting, what is a court to do? If the only option left is to apply public Constitutional Law, declaring the lawmaking entity a public one despite its formal status, should the court take that dramatic step to remedy the state action problem?

The position of a court confronting an unresolved state action problem is similar to that of a court confronting Equal Protection analysis of a legislatively imposed inequality. The issue in that case is not simply whether there is an inequality, for all laws create inequalities, but whether it is the kind that justifies a court's overriding an existing legislative choice and eliminating the possibility of a future legislative remedy. ${ }^{104}$

The relevance of comparative institutional analysis for the state action doctrine has been noted by David Strauss, who observed that "expanding the category of 'state action' is a way of putting the courts in charge of a problem." "Strauss then explained that the Carolene Products theory of the Equal Protection Clause-focusing scrutiny on those suspicious laws that disadvantage political minorities-should also "influence[] the interpretation of the state action doctrine" on account of "courts' superior capacity to deal with race discrimination issues." 106

104. Cf. 3 Ronald D. Rotunda \& John E. Nowak, Treatise on Constitutional Law: SubstanCE AND PROCEDURE $§ 18.3$ (a)(i) (4th ed. 2008) (discussing the Court's considerations in determining whether to override legislative choices under Equal Protection analysis).

105. David A. Strauss, State Action after the Civil Rights Era, 10 Const. Comment. 409, 413 (1993).

106. Id. (referring to Justice Harlan F. Stone's famous footnote 4 in United States $v$. Carolene Products Co., 304 U.S. 144, 152 n.4 (1938) ("It is unnecessary to consider now ... whether prejudice against discrete and insular minorities may be a special condition, which tends seriously to curtail the operation of those political processes ordinarily to be relied upon to protect minorities, and which may call for a correspondingly more searching judicial inquiry." (citations omitted))). 
Strauss has it right. The very same tertiary doctrines that guide courts in reviewing discriminatory laws should serve to define their role in applying the state action doctrine. In both contexts, after all, the concern is with relative institutional capacity to ensure adherence to constitutional commitments. This two-step institutional theory of state action tells us when, how, and why courts should consider their institutional competence. The political failure in state action cases lies in the appearance of unregulated private laws that present state action problems. Put another way, the courts must look for situations in which private Constitutional Law inadequately regulates private lawmaking. But spotting such a situation, like spotting a law that discriminates, is insufficient. In both cases, courts must then decide whether they are better positioned than other institutions to remedy the situation. ${ }^{107}$ And Carolene Products, as Strauss indicated, ${ }^{108}$ provides a reason and method for doing so.

I proceed from the assumption that the development of private Constitutional Law, including invalidating private efforts that amount to public legislation, ought generally to be left to legislatures and, secondarily, to administrative agencies and common law courts, both of which are subject to legislative override. This starting point is justified by a prior commitment to political branch prerogative over political decisions, including those affecting the line between collective and individual control over society.

\section{A COMPARISON OF THE THEORIES IN ACTION}

The previous Part introduced the institutional state action doctrine, a two-step institutional analysis. Legal systems generally require secondary rules that supply solutions to the problem of classifying lawmaking actors as public or private. Breaking the problem into a firststage analysis of the characteristics of the lawmaking entity (identification of state action problems) and a second-stage analysis of comparative institutional advantage in providing a solution (deciding whether courts should intervene) may not make every hard case easy, but it at least has the advantage of helping us to understand why they are hard.

In this Part, I explain how the institutional state action theory is in practice reflected in the American legal system and how it can be

107. See 3 Rotunda \& NowaK, supra note 104, § 18.3(a)(i) ("To the extent that the Justices independently determine whether the law has a purpose which conforms to the Constitution and whether the classification in fact relates to that purpose, the Justices are taking the position that the Court is able to assess these issues in a manner superior to, or at least different from, the determination of the legislature.").

108. See infra Section III.A. 
further integrated. I argue that the Supreme Court's state action decisions have largely, but not entirely, stumbled upon the correct solutions. In doing so, they may appear unprincipled, but this is only because they in fact grapple with each of the two steps of the institutional state action theory despite talking as though there is but one.

Although the Court has offered a variety of these arguments to support the line of state action decisions, none is sufficient to account for it. The institutional approach clears much of the confusion by disaggregating the two different inquiries. For example, the two-step approach explains why cases involving racial discrimination are more appropriate targets for state action findings in a way that few other theories can.

\section{A. Taxonomy}

The Court and commentators have provided a number of rhetorical positions that might map onto theoretical commitments underlying the state action doctrine. I label these Doctrinal Factors, Pure Balancing, Substance-Sensitive Balancing, State Support, Formal Identification, and Power. Each fails to capture important intuitions the others identify. And each attempts to paper over the difficult problems, either by ignoring them and making peace with instances of poor governance or by devolving them to courts to handle on an ad hoc basis. Another approach, recently pursued by Vikram Amar, ${ }^{109}$ comes closest to the analysis I propose here. It is, laudably, functional in nature and appropriately enlarges the range of intuitions to consult in thinking about state action cases to include, among other things, institutional concerns. $^{110}$

\section{Doctrinal Factors}

The first approach is an umbrella under which the other state action theoretical intuitions can be deployed as needed. It looks for touchstones of state action, components that can be balanced-though not a pure balance of rights like the balancing approaches I discuss below. Recall that the Supreme Court has identified diverse pathways to finding state action, including various forms of state participation and the performance by the putative state actor of a "public function.",11

109. See generally Amar, supra note 6, at 424-29 (arguing that certain functional considerations present a preferable approach to state action analysis).

110. See id.

111. Brentwood Acad. v. Tenn. Secondary Sch. Athletic Ass'n, 531 U.S. 288, 295-96 (2001) 
Even after one of these routes proves to be available, state action is not found when competing values of sufficient weight exist. In Brentwood, Justice Souter cited a case involving a public defender acting within the scope of her duties. ${ }^{112}$ Public employment would normally qualify as a sufficient nexus to find state action, but in Polk County v. Dodson, the public defender was employed as the state's adversary rather than its agent. ${ }^{113}$

Other relevant factors might include the monopoly position of the actor, ${ }^{114}$ the degree to which the action interferes with some important, constitutionally significant policy, the coercive power of the private entity, and the nature of the rights at stake on each side of the litigation. Some of these, as discussed below, are the hearts of theories urged as replacements for the Court's ad hoc approach.

The deficiency of this method of finding state action is clear. Not only does it fail to identify the institutional problems that functionally justify the doctrine, but it does not specify a method at all. The ad hoc approach is, essentially, a delegation to judges to use intuition-the sort of solution one might strike upon to resolve a problem that seems too complex for an algorithm but as to which "knowing it when you see it" seems to work most of the time. The true effect, though, is to generate politically acceptable answers in difficult and charged state action cases.

\section{Power}

The Power theories posit that public constitutional norms ought to apply to "powerful" private entities. "Power" is a relative term, and might refer either to (1) the quality of the power a private entity wields or (2) the extent to which a private entity can control other private parties. Examples of the former include arguments that there exists a category of functions that are inherently governmental. When a private party exercises such governmental powers, it is their quality as governmental that causes a court to apply public constitutional norms. ${ }^{115}$ The Supreme Court found state action in Terry v. Adams, citing the governmental nature of the power of a private organization that had de facto authority over candidates for election. ${ }^{116}$ But in Flagg

112. Id. at 303 (discussing Polk Cnty. v. Dodson, 454 U.S. 312 (1981)).

113. Id. at 303-04.

114. See Flagg Bros. v. Brooks, 436 U.S. 149, 159-60 (1978) (noting the importance of the monopolistic position in public function analysis).

115. See, e.g., Jesse H. Choper, Thoughts on State Action: The "Government Function" and "Power Theory" Approaches, 1979 WASH. U. L. Q. 757, 776-77 (1979); Ralph K. Winter, Jr., Changing Concepts of Equality: From Equality Before the Law to the Welfare State, 1979 WASH. U. L. Q. 741, 744 (1979).

116. 345 U.S. 461, 469 (1953). 
Bros. and Jackson, the Supreme Court found that private exercises of arguably governmental functions were not sufficient on their own to constitute state action. ${ }^{117}$

The latter type of power theory, focusing on the extent that a private party has power over other parties, certainly overlaps the former. Rather than focus on the kinds of powers governments typically have, it is fundamentally concerned with ensuring constitutional constraints on de facto coercive authority. ${ }^{118}$ Coercion, not traditional governmental functions, is the criterion for finding state action.

Power theories are on the right track, but the structural theory more precisely describes and handles the source of the state action difficulty. Very often, "powerful" private actors and combinations of such actors can be coercive in a way that mirrors legislative command. But there are at least two problems with letting the solution to the Categorization Problem turn solely on an estimate of the private party's power.

First, "power" is an imprecise term. A powerful private actor may be one that can easily accomplish its own ends, but it may not have a legislative-like ability to coerce other private parties. Some large corporations, for example, are powerful in the sense that they dominate their respective markets, obtaining perhaps the best deals on supplies, but not in the sense that they can coerce others. Like fuzzy inquiries into whether a course of conduct is generally public or private, asking whether an entity is powerful asks many questions at once and invites conflicting answers, with no criteria for sifting among them for the answer most responsive to the concerns animating the inquiry in the first place. $^{119}$

But even if power is understood to mean the ability to control a significant portion of the community, the power theory does no more than identify potential state action problems. Because the power theory is not rooted in a deeper understanding of the institutional problems behind the state action inquiry, it may not even do a good job of that. Looking for power or coercion should be proxies for the real inquiry: whether the private actor is inadequately regulated by private Constitutional Law. After all, Contract Law already makes the

117. Flagg Bros., 436 U.S. at 161 (finding no state action on grounds that "the settlement of disputes between debtors and creditors is not traditionally an exclusive public function" (emphasis added)); Jackson v. Metro. Edison Co., 419 U.S. 345, 352-53 (1974) (declining to find state action concerning privately owned utility company providing essential public service).

118. See Adolf A. Berle, Jr., Constitutional Limitations on Corporate Activity-Protection of Personal Rights From Invasion Through Economic Power, 100 U. PA. L. REv. 933, 942-51 (1952) (analyzing the theory that large corporations, because they are creatures of the state and exert great economic control over the citizenry, should be subject to constitutional restraints).

119. See infra Subsection III.B.1. 
enforcement of contracts contingent on voluntarism and includes prohibitions on unconscionable contracts or those entered under duress. Powerful entities in competition for customers are often not in a position to dictate terms to those customers. The point here is that economic power, as such, is not sufficient to show the existence of a state action problem. To the extent that it is used as an indicator, it must be remembered that it is only evidence of the problem but is not itself the problem.

At least, though, conditioning state action on a private party's possession of power is roughly aligned with the underlying institutional question - if power is understood as the ability to gain the compliance of others without true consent. Its imprecision, though, is compounded by the theory's failure to provide guidance to courts as to whether they, as opposed to other institutions, should regulate the private power at issue. It misses the second step of the two-part state action theory.

The power theory conceives of Constitutional Law horizontally, as a separate body of rights-protecting provisions that at the very least constrains public agents but that has no direct similarity to private contract law. It does not understand public Constitutional Law as a regulatory option parallel to the private Constitutional Law of our contract law, one that serves the same purposes but with a different institutional target. ${ }^{120}$ Perhaps for this reason, the theory is not expansive enough to allow courts to forbear finding state action when other institutions are sufficiently competent to amend the private Constitutional Law that would ordinarily govern. In short, the power theory-because it does not fully comprehend the institutional problem-fails to distinguish the problem of poorly regulated private entities from the question of whether courts are the proper public bodies to solve that problem.

\section{Balancing}

Balancing theories treat the state action question as a question of costs and benefits. Applying public constitutional constraints to a private actor imposes autonomy-restricting obligations on that actor; for example, by restricting the actor's ability to discriminate among potential business associates. On the other hand, not applying those constraints permits private actors to impose burdens on others. A balancing theory attempts to pick an optimal regulatory solution to this problem of alternative costs by asking a judge to weigh them.

The key to this approach is a conviction that constitutional rights are positive entitlements. For example, a private employee who faces

120. See supra Section II.A. 
termination if he or she expresses certain political views has suffered an abridgment of his or her freedom of speech. Although the Constitution is not formally concerned with this type of abridgment, a balancing view understands this speech restriction as a constitutionally cognizable cost. When this cost is greater than the constitutional costs that would be realized by imposing public Constitutional Law on the adverse private actor, a balancing theory would find state action.

Erwin Chemerinsky is perhaps the staunchest advocate of the balancing approach, arguing that the state action doctrine should be eliminated and replaced with a balancing test. ${ }^{121}$ But other commentators also have urged some form of balancing test. ${ }^{122}$ Pure balancing theories normally depend on denying the reality of a formal line between public and private action. ${ }^{123}$ The question of state action is, for these theorists, one of a policy concerning those competing personal interests that have resonance in the language of rights.

As the Supreme Court put it in Marsh: "Whether a corporation or a municipality owns or possesses the town the public in either case has an identical interest in the functioning of the community in such manner that the channels of communication remain free." 124 Rights, in this formulation, are immunities that travel with the actor, guarding against involuntary abrogation from whatever the source, only yielding when weightier rights are at stake on the other side.

A variation on the balancing theory, substance-sensitive balancing, also takes its cue from Marsh, and understands that the nature of the rights on either side is perhaps more important than any quantitative understanding of the degree of infringement of those rights. For example, the Court in Marsh stated, "When we balance the Constitutional rights of owners of property against those of the people

121. Chemerinsky, supra note 37 , at 506.

122. See, e.g., Van Alstyne \& Karst, supra note 37, at 7-8 (arguing that rather than searching for a unitary state action formula, courts should consider three aspects: (1) the personal interests of the parties; (2) the impact on these personal interests of a decision whether national authority may intervene; and (3) the effect of such a decision on the policy of encouraging local responsibility).

123. See, e.g., Paul Brest, State Action and Liberal Theory: A Casenote on Flagg Brothers v. Brooks, 130 U. PA. L. Rev. 1296, 1301 (1982) (noting that the state is implicated "in every 'private' action not prohibited by law"); Chemerinsky, supra note 37, at 524 ("[S]tate action is present in all private violations of constitutional rights."); Robert J. Glennon, Jr. \& John E. Nowak, A Functional Analysis of the Fourteenth Amendment "State Action" Requirement, 1976 SuP. CT. REV. 221, 229-30 (1976) (arguing that a state permitting "unconstitutional" private action no less deprives the injured citizen of his rights than a state affirmatively infringing on those rights).

124. Marsh v. Alabama, 326 U.S. 501, 507 (1946). 
to enjoy freedom of press and religion, as we must here, we remain mindful of the fact that the latter occupy a preferred position."125

The rhetorical approach here suggests that while a balance is a "must," the weights of rights on either side depend on their nature. The First Amendment rights of speakers, the Court observed, are "fundamental," lying "at the foundation of free government." ${ }^{26}$ On the other hand, the public-like operation of the property diminished the private property rights to exclude: "The more an owner, for his advantage, opens up his property for use by the public in general, the more do his rights become circumscribed by the statutory and constitutional rights of those who use it." "27 The Court argues that, in a balance of constitutionally cognizable harms, not all infringements are the same.

The trouble with using a balancing approach illustrates the benefits of the institutional theory. First, as a theory of selecting between private and public Constitutional Law, it fails miserably. A balance of rights is likely to be insensitive to the institutional considerations that have led to the distinctions between the two bodies of secondary laws. Instead, the balancing focuses on the relative impact on the parties of the decision whether to apply public Constitutional Law rather than private Constitutional Law, without explicitly focusing on public Constitutional Law's comparative advantages and disadvantages to private Constitutional Law. While that determination could possibly replicate the suitability analysis I have urged, it would do so only indirectly while being resistant to rule-like formulations and the creation of categories. And weighing impacts to rights obscures, rather than illuminates, the state action doctrine; even a constitutional regulation that results in little cognizable harm to a state action defendant might be a very poor regulation, in that the state action defendant has no cognizable reason to serve as the agent of the plaintiff or the public at large.

Second, the theory leaves no room for other institutions to solve state action problems in more finely tuned ways. Balancing would cause the state action determination to turn only on a judicial evaluation of competing rights. A critical aspect to resolving these difficult cases is the introspection and evaluation of the political landscape that the second step of the institutional analysis requires. Some balancing approaches would allow courts to consider such things, ${ }^{128}$ but it would be better to acknowledge that the second step is a threshold, not a factor.

125. Id. at 509 (footnote omitted).

126. Id.

127. $I d$. at 506.

128. See, e.g., Van Alstyne \& Karst, supra note 37, at 34-35 (arguing for a consideration of the impact of finding state action on the policy of local control in a test that would otherwise 


\section{Formal Identification}

Some commentators have rejected altogether courts' unilateral application of public constitutional principles to entities that are not formally public. ${ }^{129}$ For example, Richard Kay argues that the Constitution should protect individual rights only against abrogation by Congress, the President, and other state and federal agents acting under controlling law. ${ }^{130}$ Although this approach would represent a radical departure from the Court's doctrine, being inconsistent with Shelley and Marsh to name the most obvious examples, it is not entirely inconsistent with the abstract state action doctrine.

The Formal approach does not deny the existence of state action problems, and it does not argue against regulations that import public constitutional principles to solve such problems. But it does deny that step two should, in a significant category of cases, be resolved to permit courts to provide such regulations. That, after all, is what step two does. It asks courts to resolve whether other institutions are capable of supplying needed public-oriented regulations on private actors and, if not, whether the courts are. One might believe courts should always resolve this in the negative on grounds that they are never better suited than other branches to solve the problem or on grounds that, perhaps empirically, there are almost always other institutions that, even if laboring under some detriment with respect to the question, have the capacity to provide responsive solutions.

Terry and Shelley are but two important data points that help show why this view is mistaken. In each case, the existing private Constitutional Law was controlled by majoritarian forces that had an active interest in helping to subvert the goals of public Constitutional Law. ${ }^{131}$ Concerted private action was actually used as a substitute for legislation, while the governing private Constitutional Law was designed for other, more disaggregated forms of private action. ${ }^{132}$ But the reason this substitution was effective, the reason that other institutions failed to supplement the private Constitutional Law applicable to these defendants, was the complicity of the legislature, marking a failure of majoritarian politics to align private secondary

balance the harms of the decision to private parties).

129. See, e.g., John Fee, The Formal State Action Doctrine and Free Speech Analysis, 83 N.C. L. REv. 569, 574 (2005) (advocating a formal approach to state action that recognizes "without exception that only governmental actors are subject to constitutional rules").

130. Richard S. Kay, The State Action Doctrine, the Public-Private Distinction, and the Independence of Constitutional Law, 10 Const. CoMmEnT. 329, 342-43 (1993).

131. Terry v. Adams, 345 U.S. 461, 469-70 (1953); Shelley v. Kraemer, 334 U.S. 1, 19-20 (1948).

132. Terry, 345 U.S. at 469; Shelley, 334 U.S. at 19-20. 
rules with controlling public policy. These cases demonstrate the essential role that courts can and should play in those rare cases when serious state action problems are immune from political correction.

Still, there has been support from the Supreme Court for this formal position, at least in some cases. Justice O'Connor, in Lebron, appeared to have accepted it: "[T] he conduct of a private actor is not subject to constitutional challenge if such conduct is 'fundamentally a matter of private choice and not state action." "133 Read too strongly, this would appear to contradict Shelley, ${ }^{134}$ but I do not think this was Justice O'Connor's intent. Her position was, rather, a useful articulation of an intuition, one the institutional theory makes explicit: that courts may not normally be the best bodies to apply substantive, constitutional-type restrictions in areas ordinarily governed by private Constitutional Law.

\section{Functional Theories}

More recent efforts to understand the state action miasma have made strides forward by focusing on function rather than debates over malleable, formal labels. Vikram Amar has set out three possible groundings for a functional state action theory, the first two of which are institutional in nature. ${ }^{135}$ First, he cites federalism as a possible reason to avoid expanding the category of actors against whom the Equal Protection and Due Process Clauses apply. ${ }^{136}$ If these clauses' application is broad, then so too is Congress's enforcement power under Section Five of the Fourteenth Amendment-broad "in a way that

133. Lebron v. Nat'l R.R. Passenger Corp., 513 U.S. 374, 409 (1995) (O'Connor, J., dissenting) (quoting Edmonson v. Leesville Concrete Co., 500 U.S. 614, 632 (1991) (O'Connor, J., dissenting)). In the Establishment Clause context, Justice Thomas has similarly written in support of a strong, formal public-private distinction: 'If aid to schools, even 'direct aid,' is neutrally available and, before reaching or benefiting any religious school, first passes through the hands (literally or figuratively) of numerous private citizens who are free to direct the aid elsewhere, the government has not provided any 'support of religion." Mitchell v. Helms, 530 U.S. 793, 816 (2000) (plurality opinion).

134. The obvious counterargument is that Shelley involved a willing buyer and willing seller, prevented from transacting by the state. Shelley, 334 U.S. at 19. That, however, would be a formalistic evasion of what happened. The covenant at issue represented a regulatory right of a neighbor that would ordinarily be called a property right and enforced, regardless of the wishes of sellers and buyers. The dispute in Shelley arose because of the private choices of neighbors to grant each other regulatory rights regarding racial exclusion.

135. Amar, supra note 6, at 425-29. The third is that "many constitutional rules would be unreasonably intrusive if we applied them to all private behavior," and so the doctrine that insists on state action before applying them protects a "cluster of privacy and autonomy considerations." Id . at 429 . That is indeed a function of the default categorization. At the least, it describes typical values behind the political choices concerning which activities should generally be left to Contract Law and its consent-based structure.

136. Id. at 425-26. 
threatens local autonomy, experimentation, and compromise that considers and balances local conditions and complexities." ${ }^{137}$ Although Amar concludes that the breadth of Congress's power under the Commerce Clause currently renders this concern of little practical importance, it does echo the second step of the institutional theory. ${ }^{138}$ His citation of separation of powers as a second functional justification goes even further in the direction of the second step. ${ }^{139}$ First noting the general preference for policymaking by legislatures, Amar echoes the justifications for the second step of the institutional theory: that legislatures are better at gathering data and crafting finely tuned rules that are more responsive to the detailed circumstances of the regulated actors. $^{140}$

This line of thinking is similar to the institutional approach. While Amar would use these functional considerations as part of a more ad hoc test, ${ }^{141}$ they at least focus on one important question: the wisdom of using courts to solve problems like those arising in the canonical state action cases. The full institutional theory tells us when and how Amar's justifications, among others, should be deployed. Examples help to demonstrate how this is so.

\section{B. Institutional Theory in Action}

The distinctive character of the institutional theory is better appreciated with its application. I will briefly analyze the theory's application to several previously decided state action cases. In doing so, the contrast with existing theories and doctrine will become clear. The institutional theory, however, reaches even beyond state action. Once one understands the problem in state action cases to be one of mismatched primary and secondary rules, an obvious question arises: Are there formally public actions that would be better governed by private Constitutional Law? In other words, are there private action problems as well as state action problems? I close by arguing that there are.

\section{Shelley}

Any state action theory must grapple with Shelley $v$. Kraemer, the paradigmatic case raising the Categorization Problem. ${ }^{142}$ First note that

137. $I d$. at 426 .

138. Id. at 426-27.

139. Id. at 427-28.

140. Id. at 428 .

141. Id. at 433-37.

142. Esper went so far as to call it "the Taj Mahal of state action problems." Esper, supra note 42 , at 715 . 
neither the formal identification theory nor an unmodified power theory would replicate the result in Shelley. Since the parties making and enforcing the covenants were undeniably private entities, the formal identification theory would clearly find that no state action existed. Although Shelley itself purported to find state action in a court's enforcement of a private covenant, if that were sufficient, all private agreements would be subject to public constitutional review before enforcement. Court enforcement was not a determinative reason for the decision in Shelley, and so the formal identification of the judge as the public actor is insufficient.

The power theory likewise fails to harmonize with Shelley unless it is transformed into a collective-action principle resembling the first step of the institutional theory. The homeowners seeking to enforce the racist covenants in Shelley were not the sort of powerful private actors that the power theory imagines as state-like. Their coercive capacity, with respect to the issues in Shelley, extended only to a few properties. Again, if that were sufficient, the power theory would be a nullity, as every private agreement represents some quantum of power, represented by the consideration, on each side.

To offer an effective but affirmative answer to the state action question in Shelley, therefore, the power theory would need a broad understanding of the entities that a court would analyze in a given case for state action-triggering power. If it were known that the widespread use of covenants made it virtually impossible for nonwhites to buy or occupy homes in white neighborhoods, then we could say that the market has served a coordinating function, delivering a near-uniform private rule authored by disaggregated private lawmakers. Perhaps the sort of power that triggers state action can be found not only in individually powerful private actors but in aggregations of market actors who collectively wield power over other market participants.

This conception of the power theory begins to capture the essence of the first step of the institutional theory. The institutional theory is, first of all, more precise in its first step. It is not merely the power of the market in the abstract nor even its power to push a uniform rule that satisfies the first step, but the coercion to comply with that rule. In addition, the power theory would still suffer from the lack of a second step analyzing the institutional appropriateness of courts as state action problem solvers. This deficiency causes too much to turn on a finding of "power," as doing so triggers public constitutional review even when such review is institutionally inappropriate. That is, it fails to distinguish those cases in which courts are needed to solve the problem from those in which they are not, and in which court involvement may 
bar better, more finely tuned regulation. ${ }^{143}$ As a result, the theory would not be able to explain why race should be a trigger for finding state action.

The problem is that if the power theory yields the result in Shelley it proves far too much, for it would dictate the application of public constitutional rules by courts in every instance of market-coordinated action by otherwise diffuse private actors. This does not match our practice, which finds no state action, for example, when markets deliver certain kinds of automobiles but not others, when markets settle on particular forms of transacting in real estate, or when a town supports a few newspapers, none of which are libertarian in viewpoint. None of these has been found to be state action, and the institutional theory would not label them state action either, for reasons that will be further examined below.

In contrast to the Court's holding and other theoretical approaches, the institutional theory captures the essence of what is really bothersome about Shelley, distinguishing it from other instances of covenant enforcement. First, we ask whether the private rules that were enforced raised unresolved state action problems. As we have seen, ${ }^{144}$ covenants that run with the land raise, generally, a state action problem. But this problem is cured by the agency-policing doctrines of, inter alia, touch and concern.

Shelley, though, involved a further problem. The defect was not the binding, by an individual covenant, of future landowners by unrepresentative agents. Rather, there was a state action problem on account of the widespread use of covenants to create a de facto scheme of racial segregation. That was the reality in Shelley:

The St. Louis Real Estate Exchange openly coordinated the city's numerous 'neighborhood improvement associations' in a widespread pattern of covenanted segregation. Indeed, widespreadness was exactly what made RRCs [racial restrictive covenants] so pernicious. A handful of smallscale RRCs could have been insulting and annoying, but they could scarcely have had much impact in constricting of housing opportunities for African Americans. But widespread RRCs threatened to do just that, in a manner

143. Again, the analogy to Equal Protection may be helpful. The function of levels of scrutiny is to reserve serious review for those inequalities that courts are best positioned to remedy relative to legislatures. All laws impose inequalities. Only some of those reveal institutional defects in legislatures. See supra notes 104-06 and accompanying text.

144. See supra Subsection II.B.2.a. 
that was contrary to the ordinary American precepts of property law favoring free alienability of real estate. ${ }^{145}$

The first step of the institutional theory would find no state action problem in a world in which racial covenants were isolated occurrences and provided no general bar to minorities wishing to live in neighborhoods dominated by majorities. ${ }^{146}$ Such isolated covenants would not actually coerce individuals into particular channels, ${ }^{147}$ as the market would provide choice. And the limited coercion involved in individual covenants is governed by touch and concern and other doctrines. Therefore, the private act of agreement would have no compulsory effect on others, making private Constitutional Law, the ordinary law of covenants, the appropriate body of secondary rules to govern such acts. ${ }^{148}$

This, however, was not the situation in Shelley. And although the Court failed to grapple with the social reality behind the case, that reality would be crucial for a direct application of the institutional theory. ${ }^{149}$ The fact that the real-estate market operated in a compulsory way, that as to the segregation mandate there was a monopoly of practice if not a monopoly of providers, is enough to conclude that the private agreements at issue, in the aggregate, had binding effects on nonparties. They were legislative in character, and without the agencypolicing provisions of public Constitutional Law, nothing prevented that legislation from deviating from what the community requires of public

145. Rose, supra note 3, at 195 (footnote omitted) (citing Clement E. Vose, CauCasians Only: The Supreme Court, the NAACP, ANd the Restrictive Covenant Cases 106-07 (1959)).

146. It is, however, indeed difficult to imagine a world — with our own history-generally free of racial discrimination but in which there are no state or federal laws prohibiting private racial discrimination in housing. But it is in such a strange world that Shelley would not have been needed.

147. Cf. Jed Rubenfeld, The Right of Privacy, 102 HaRv. L. REv. 737, 784-87 (1989) (discussing, in the right of privacy context, the difference between laws that remove options and laws that coerce by determining courses of conduct).

148. Of course, the presence of a state action problem is not the only reason to regulate a private transaction. A state's judicially enforceable public policy or legislatively enacted statutes ought to block even small-scale instances of racial discrimination that have deleterious, if not compulsory and therefore public in nature, effects on the public interest.

149. In fact, to explain the result, the broader set of facts must have been crucial in the Supreme Court's indirect application of the same theory. As argued supra, the primary ground for state action given, judicial enforcement, does not distinguish Shelley from cases in which there is no state action. It is difficult to believe that the Court would have ruled as it did had racist covenants not been widespread enough a practice to approach in fact, if not in law, a racist-zoning scheme. 
legislation. In short, the racist covenant scheme created a state action problem, unremedied by the state of Missouri. ${ }^{150}$

The institutional theory thus requires that we move to the second step of the analysis: Are the political institutions peculiarly disabled from ameliorating the state action problem in this category of cases by modifying the applicable private Constitutional Law to incorporate the needed public Constitutional Law principles? In answering this, we see the important role played by the fact of race discrimination in Shelley. Indeed, the second step explains why the protection of unpopular speakers and racial minorities intuitively raises the state action question where other contents of private rules would scarcely raise an eyebrow.

The counter-majoritarian nature of courts specially qualifies them to act in cases in which discrete and insular minorities will be unable to protect themselves within the political institutions. ${ }^{151}$ Because the uncorrected state action problem in Shelley was structurally resistant to political cure, on account of the relative political powerlessness of those harmed by the private zoning scheme, the Court was the institution best situated to solve the problem. ${ }^{152}$ Cases like Shelley, which involve coercive private laws that single out political minorities for unfavorable treatment, reveal institutional failings that justify a preference for judicial resolution. ${ }^{153}$

Before leaving Shelley behind, it is worth observing again that the institutional theory would find that most instances of judicial enforcement of covenants do not invoke the state action doctrine. In the vast majority of cases, the only state action problem a covenant might raise is remedied by the touch and concern doctrine and related, but ex

150. Note that this analysis applies to any market in which (1) there is a near-uniform rule included in all agreements, (2) there is a monopoly of practice, and (3) the market delivers something that citizens cannot easily avoid or substitute. Such a market creates a state action problem but not necessarily one that should be remedied, under the second step, by courts' application of public Constitutional Law.

151. This is not the only way in which courts may have a clear advantage over other governmental institutions. Nor, in fact, do they always have this advantage. But it is the one on which I focus for the present.

152. I admit to harboring some lingering uncertainty, even under the facts in Shelley, about whether the Court would have been the best situated institution to solve the problem if the national situation had been a little different. The effect of the state action finding is, perhaps unfortunately, to remove regulatory discretion from the political branches. Had the political institutional failure been only at the state level with some significant prospect that Congress might have or soon develop the capacity to regulate, then there might have been a case for judicial restraint. Unfortunately, at the time of Shelley, civil rights legislation was years away. In any event, the longtime failure of any political branches in a circumstance paradigmatic of political malrepresentation, in my view, strongly supported a state action finding absent clear signals that a political solution was imminent.

153. See supra notes $104-06$ and accompanying text. 
post, doctrines intended to deprive poorly governing covenants of effect. It should also be obvious that judicial enforcement outside the covenant setting is not a trigger for state action.

Even in cases in which the market settles on some options to the exclusion of others, like in the above example of only certain cars or newspapers available for purchase, there is almost certainly no state action. In many cases, we would not make it past the institutional theory's first step. A market that makes available only televisions over twenty inches is, indeed, reflective of a privately formulated, if in a disaggregated manner, rule concerning the appropriate sizes of televisions. But this rule does not bind others in any significant way. It is difficult, especially these days, to conceive of the unavailability of smaller televisions as coercive, as forcing non-consenting others to conform to the private rule. Opting out of purchase altogether is possible. Most goods are like this, and, indeed, because of their role in the receipt of information, televisions are closer to the coercion line than most.

Disaggregated market forces that do create a private, coercive rule of the kind that I label a state action problem do not necessarily come under public Constitutional Law, as very often the second step renders them inappropriate targets for regulation by courts. Even if we concluded that television sets, perhaps because of their informationproviding function, were a virtual necessity of citizenship, so that a market-produced rule providing restrictions on ownership would be necessarily coercive, the question of whether courts should regulate such rules with public Constitutional Law would remain to be decided. One would need a reason to think that the political branches were structurally unable to do so. Unless the rule provides majority benefits at minority expense, it is unlikely such a reason exists.

\section{Marsh}

Marsh v. Alabama arose from a criminal trespass prosecution of a Jehovah's Witness who continued to distribute religious literature in a company-owned town after being asked to leave. ${ }^{154}$ Gulf Shipbuilding Corporation owned land that contained "residential buildings, streets, a system of sewers, a sewage disposal plant and a "business block," all constituting Gulf's privately owned town called Chickasaw. ${ }^{155}$ In the Court's words, "the town and its shopping district are accessible to and freely used by the public in general and there is nothing to distinguish them from any other town and shopping center except the fact that the

154. 326 U.S. 501, 502-03 (1946).

155. Id. at 502 . 
title to the property belongs to a private corporation." ${ }^{\text {"156 }}$ Unlike an ordinary town, however, the private owners of Chickasaw enforced a rule prohibiting solicitations of any kind without prior permission, and they refused to grant permission to Marsh. ${ }^{157}$

As the Court pointed out, enforcement in an ordinary, public town of such a rule against a religious proselytizer like Marsh would obviously be unconstitutional. ${ }^{158}$ As the Court put it, the question, then, was whether "those people who live in or come to Chickasaw [can] be denied freedom of press and religion simply because a single company has legal title to all the town?"159 As has been discussed, the Court performed a rights-sensitive balancing test to decide that the answer was no. ${ }^{160}$

The institutional theory, however, reveals a more complex legal scene. We first must come to grips with what laws are being applied and scrutinized. Although she contested her conviction under a criminal statute, Marsh's argument was not really that the trespass statute itself was unconstitutional. The argument, in substance, was that the Constitution barred Gulf from formulating and enforcing the private rule for granting and revoking licenses on which the trespass statute was parasitic. ${ }^{161}$ That manifested, formally, in a challenge to the trespass statute as it was applied. But it was Gulf's prior restraint, standardless licensing, and apparent total bar on Jehovah's Witnesses' proselytizing that were alleged to be unconstitutional. And, indeed, that was what the Court analyzed for constitutionality, as was the case for the equivalent, but public, rules that were analyzed for constitutionality in cases involving ordinary towns. ${ }^{162}$

Applying the first step of the theory, we ultimately ask whether the town's rulemaking was poorly governed by private Constitutional Law. Whether the town's rules amounted to a state action problem depends on whether they were essentially obligatory on others, so that their binding nature turned on something other than the consent that private Constitutional Law assumes. Privately formulated rules for licenses to visit private homes and most businesses do not have this quality. Visiting a neighbor and shopping in a particular store are almost always

156. $I d$. at 503 .

157. Id.

158. Id. at 504-05 (citing, inter alia, Lovell v. Griffin, 303 U.S. 444 (1938) (striking down a scheme requiring permission from the City Manager before distributing literature of any kind)).

159. Marsh, 326 U.S. at 505.

160. $I d$. at 509.

161. Id. at 504 .

162. Id. at 504-05. 
voluntary in a pure sense. Dislike of the rules of one establishment will lead to visiting another. ${ }^{163}$

An entire town is another matter. Exit is, of course, formally an option. But a town, as a collection of residents and businesses, is such an interactive locus that avoiding it becomes increasingly difficult with its size. As avoidance becomes more difficult, the inference grows that appearing there and remaining there are driven by needs that, for many, make the terms of the license essentially compulsory. In that case, it would be impossible to say that the private lawmakers - the parties to the license-made a welfare-enhancing decision by exchanging core freedoms for the right to use ordinary town-like resources.

More importantly, even if many individuals in Chickasaw had truly made a Pareto efficient exchange with Gulf, the private rule barred others who found the terms of the rule unacceptable. Even though exit was an option, the private rule promulgated by Chickasaw and cooperated in by town residents and businesspersons had a binding effect on outsiders-barring them not just from a particular business among many but from an entire region of commerce. The point, in this step, is not to make a judgment about whether doing so violates fundamental liberties, whatever those might be. Rather, we need only establish that the rule had regulatory effects on those who did not make it but would nonetheless have to live under it. The licensing rule of an individual establishment does not, in general, have this property. But as the area covered by the private rule increases, so too does the regulatory effect.

Perhaps a single, private town, especially one composed of likeminded adherents to an alternative normative regime, does not raise a state action problem. ${ }^{164}$ In such a case, the role of consent is far greater, in that the more separatist the community, the more its rules can be seen to result from private, institutional competence, and the less we should be concerned that others will be swept into a regime they had no hand in making on account of the economic and geographic power of the town. Chickasaw was, as the Supreme Court pointed out, not at all distinct from ordinary private towns. 165

Moreover, the very idea of a private town was not at all unusual. While today company towns seem antiquated, ${ }^{166}$ the Marsh Court noted

163. The problem of a uniform rule among disaggregated private entities - a rule barring all women, for example, from all of a town's shops where no one shop is essential-is taken up infra.

164. Peñalver, supra note 101, at 1967-71.

165. Marsh, 326 U.S. at 503.

166. But not unheard of. See Hardy Green, The Company Town 6 (2010) (identifying Columbus, Indiana, and Corning, New York, as company towns that live on, and proclaiming 
that they were common at the time. "In the bituminous coal industry alone, approximately one-half of the miners in the United States lived in company-owned houses in the period from 1922-1923. The percentage varied from 9 per cent in Illinois and Indiana and 64 per cent in Kentucky, to almost 80 per cent in West Virginia."167 If there were near-uniform rules across many of these towns, it would support the finding of a state action problem, as the uniformity of covenant practice did in Shelley. Here, though, it would suffice to find a state action problem if there were a single, company-owned town sufficiently integrated into (even if not the whole of) the local economy, so that avoidance was a significant burden.

As to the second step, the above discussion is highly relevant. Recall that we ask in this step whether the Court should undertake what ought to be a highly unusual step. Should it apply the public Constitution to private conduct, breaking with the formal identification theory? The institutional theory argues that it should only do so when the Court is far better suited, at the margin, to solve a state action problem than other institutions are. The most common, though possibly not the only, reason the Court might be best suited to solve such a problem is that the private rule disadvantages a group that lacks political power to protect itself in other areas of government. ${ }^{168}$

Marsh, like Shelley, does seem to be a case involving a private rule presenting a state action problem that discriminates against political minorities. It is a situation in which it might be difficult for other institutions to introduce ameliorating public-law-inspired secondary rules into the governing private Constitutional Law. Perhaps that is enough, but perhaps in exercising this blunt and unusual authority, the Court could look more deeply into the likelihood that the state would better represent minority interests in private towns in the future. Is there already an extensive regulation of such towns, in which speaker protection is a lacuna? And if so, are there regulations that could lead us to believe that the lack of protection here is unintentional, owing to lack of foresight? These sorts of questions attempt to gauge the need for unusual federal court intervention.

In Marsh, there is at least some indication that the Court recognized that the state had no intention of wielding any unusual regulatory authority: "The State urges in effect that the corporation's right to control the inhabitants of Chickasaw is coextensive with the right of a

corporate campuses like Pepsico's Purchase, New York, and Google's Googleplex in Mountain View, California, to be examples of a new form of company town).

167. Marsh, 326 U.S. at 508 n.5.

168. See supra notes $104-06$ and accompanying text. 
homeowner to regulate the conduct of his guests." Alabama's apparent lack of interest in solving the state action problem in Marsh and the Court's apparent concern that privately owned towns were a significant feature of the cultural landscape, primarily populated by miners and workers of modest means, probably justified its view that it had an institutional advantage in setting second-principle baselineshere, prohibiting private rules discriminating against speakers.

\section{Other Cases}

In Terry v. Adams, a private group in Texas, the Jaybird Democrats, held private elections restricted to whites. ${ }^{170}$ Its membership included, by definition, all white voters in the county. ${ }^{171}$ Candidates ran within the organization, and victorious candidates would then run unopposed in the Democratic primary, in which the losers of the private primary did not appear. ${ }^{172}$ The effect was to create an all-white primary. ${ }^{173}$ The Supreme Court found the procedure unconstitutional under the Fifteenth Amendment, holding that " $\mathrm{t}]$ he Jaybird primary has become an integral part, indeed the only effective part, of the elective process that determines who shall rule and govern in the county" and that "[ $\mathrm{t}] \mathrm{he}$ effect of the whole procedure ... is to do precisely that which the Fifteenth Amendment forbids."

The institutional theory handles the case in a straightforward manner. The rules of the Jaybird Party, though formally private, were binding on nonmembers, namely nonwhite voters. These rules, therefore, created an obvious state action problem. Further, under step two, the need for federal court intervention could not have been plainer. We have in Terry an attempt at racial discrimination in elective office, in a situation in which the suspicion is high that the state has willfully decided not to regulate on its own and in which the minority groups harmed by the private rule lack the political representation that could effectively win regulation.

In Jackson v. Metropolitan Edison, ${ }^{175}$ a private electricity company had a state-sanctioned monopoly on service to a particular area of Pennsylvania. ${ }^{176}$ Because of the nature of the service it provided, it was heavily regulated by the state. The plaintiff alleged that the company

169. Marsh, 326 U.S. at 505-06.

170. 345 U.S. 461, 462-63 (1953).

171. Id. at 463 .

172. Id.

173. Id.

174. Id. at 469-70.

175. 419 U.S. 345 (1974). 
had turned off her electric service without due process of law. ${ }^{176}$ Asserting that the company's termination of her service was state action, she sought to challenge the termination rules under the more aggressive second-principle derived rules of due process instead of the second-principle derived rules of unconscionability (and related doctrines). ${ }^{177}$

Justice Rehnquist, writing for a Court that had passed the high-water marks of state action reached in cases like Shelley, Marsh, and Terry, disclaimed reliance on the asserted monopoly status of the utility or of its connection with the public interest. ${ }^{178}$ Rather, looking for a concrete connection between formal state officials and the conduct in the case, the Court found nothing "to connect the State of Pennsylvania with respondent's action so as to make the latter's conduct attributable to the State."179

Jackson is interesting, because rules promulgated by a monopoly provider of electricity surely present state action problems. Both the majority and some justices in dissent failed to appreciate the quality of the argument that electricity is an "essential public service."180 That description of electrical service is another way of observing that citizens, in the modern day, cannot realistically opt out of procuring it. And if the provider is a monopoly, so that shopping for service involves moving one's abode, then the provider's privately created rules will not be well-governed by private Constitutional Law that assumes consent. And, indeed, heavy state regulation of utilities is intended to be responsive to this state action problem.

The Jackson case is difficult because of the second step. On the one hand, lax termination procedures that affect mainly customers who have trouble paying their bills would seem to be the sort of rules that might

176. $I d$.

176. Id. at 348 .

177. See supra notes $66-73$ and accompanying text.

178. Jackson, 419 U.S. at 351-53.

179. Id. at 358 .

180. See, e.g., id. at 353 (rejecting "the contention that the furnishing of utility services is either a state function or a municipal duty"); $i d$. at 371 (Marshall, J., dissenting) (recognizing the functional importance of how essential a service is but focusing on traditional association with government). The narrow view, the "find the state" view, of essential public services arises because of the lack of a second step in the state action analysis. Justice Marshall speculated that the majority's reluctance to apply due process to the company was "likely guided in part by its reluctance to impose on a utility company burdens that might ultimately hurt consumers more than they would help them." Id. at 373. This, he suggested, was owing to the expense of hearings and the like. Id. The two-step institutional theory would recognize situations in which a superficially unresolved state action problem was in fact a best-interests, legislative solution to the problem. Where it is not clear that courts are needed to resolve such problems, they should leave them for better equipped political institutions. 
not receive enough political attention to be well-regulated. On the other hand, there were in fact state efforts to solve these problems, as reflected by the extensive regulatory environment in which the company operated. $^{181}$ The very reasons Justice Douglas cited to support the presence of state action, namely the degree of the state's involvement in requiring the company's rules to include an obligation to provide reasonable notice, are reasons to suspect that federal court involvement may be inappropriate. ${ }^{182}$ Where the state is already involved in importing public constitutional principles into the secondary law governing private parties, courts should be leery of displacing that role, absent signals that the state is committed, because of capture or incapacity, to poor governance. Critical to deciding whether this is the case might be direct evidence of private capture, evidence of other areas within the regulations that irrationally disfavor poorer residents, or even individual regulations so deficient that they are difficult to explain without reference to institutional bias. ${ }^{183}$

Justice Marshall suggested that the problem of courts' imposing due process rules on private parties, displacing private preferences for public conceptions of fairness between the parties, could be ameliorated by "allowing various private institutions the flexibility to select procedures that fit their particular needs." ${ }^{184}$ In areas in which the political institutions are not peculiarly disabled from doing so, such flexibility in regulations responsive to state action problems could well come about. Importantly, the design of such means is almost certainly better produced administratively or legislatively (or even by common law courts adopting, instead of due process explicitly, modestly heightened unconscionability standards for certain classes of cases) than by federal courts. While Justice Marshall argued that the Court's finding state action would not necessarily mean an all-or-nothing application of state-like procedural rules, his argument also tends to promote the relative desirability of administrative rather than judicial regulation. ${ }^{185}$

181. Id. at 357 ("The nature of governmental regulation of private utilities is such that a utility may frequently be required by the state regulatory scheme to obtain approval for practices a business regulated in less detail would be free to institute without any approval from a regulatory body.").

182. Id. at 361-62 (Douglas, J., dissenting).

183. I should also emphasize that the state's own secondary regulations are themselves subject to constitutional review. To the extent that they mandate procedures that are deficient, there is no question of state action standing in the way.

184. Jackson, 419 U.S. at 372 (Marshall, J., dissenting).

185. See, e.g., Int'l News Serv. v. Associated Press, 248 U.S. 215, 267 (1918) (Brandeis, J., dissenting) ("Courts would be powerless to prescribe the detailed regulations essential to full enjoyment of the rights conferred or to introduce the machinery required for enforcement of such regulations."). 


\section{Private Action Problems}

The institutional approach to state action reorients the inquiry from finding an exception to private actor immunity to the Constitution to responding to the Categorization Problem of public and private lawmakers. Once this move is made, it is obvious to ask whether the categorization can be problematic in the other direction. Can public Constitutional Law be a poor match for a formally public entity that, as to particular actions, functionally resembles a private entity?

Taking a cue from the methods we used to identify instances of private lawmaking that are poorly governed by private Constitutional Law, mainly looking for laws that had some de facto binding effect on non-consenting parties, we might ask whether there are public officials whose rulemaking primarily affects a governmental interest in a way that we desire to be self-interested. The prevailing characteristic of private lawmaking as self-interested is what led us to insist on consent as, in general, a primary criterion to gauge the appropriateness of the usual private Constitutional Law regime. Public Constitutional Law, in contrast, is generally premised on ensuring good agency for broader public interests.

A search for situations in which, contra the usual, self-interest in relation to a citizen is an appropriate governmental objective leads us to the case of public employee speech. Government entities, of course, have very limited authority to impose consequences on speech by private persons. But government entities are also expected to be effective, and their interest in running an office efficiently is similar to that of a private employer. As the Supreme Court put it in Garcettiv. Ceballos, "Government employers, like private employers, need a significant degree of control over their employees' words and actions; without it, there would be little chance for the efficient provision of public services." 186 In other words, ordinary public Constitutional Law would do a poor job regulating government in its role as employer, in which it should pursue, to some extent, self-interested policies. ${ }^{187}$

186. 547 U.S. 410, 418 (2006). See also Waters v. Churchill, 511 U.S. 661, 671 (1994) (plurality opinion) (" $[\mathrm{T}]$ he government as employer indeed has far broader powers than does the government as sovereign.").

187. See, e.g., Waters, 511 U.S. at 674-75 ("Rather, the extra power the government has in this area comes from the nature of the government's mission as employer. Government agencies are charged by law with doing particular tasks. Agencies hire employees to help do those tasks as effectively and efficiently as possible. When someone who is paid a salary so that she will contribute to an agency's effective operation begins to do or say things that detract from the agency's effective operation, the government employer must have some power to restrain her. The reason [a] governor may ... fire [a] deputy is not that this dismissal would somehow be narrowly tailored to a compelling government interest. It is that the governor and the governor's 
In Pickering v. Board of Education, the Court described the public employee speech problem as involving "a balance between the interests of the [employee], as a citizen, in commenting upon matters of public concern and the interest of the State, as an employer, in promoting the efficiency of the public services it performs through its employees." "188 It is no accident that this reminds us of Marsh, in which the Court understood itself as balancing the rights of the landowner against the speech rights of Marsh. And it is also no accident that the Court has at times recast, for the better, the nature of the balance as one more resembling the concerns of the institutional theory-that between the government's responsibilities as sovereign and those as employer. ${ }^{189}$

The employee speech cases establish that the Court has not applied a simple, formal identification theory on this side of the Constitutional Law axis either. Instead it has (1) identified a private action problem with the application of ordinary public Constitutional Law to employee speech cases, and (2) borrowed principles of private Constitutional Law to correct the problem. This borrowing consists of allowing what amounts to "for cause" termination when the public employee's speech disrupts the efficiency of the government office. ${ }^{190}$

There is much more to examine on this side of the lawmaking Categorization Problem. Just as the various state action approaches I examined and rejected above have valuable intuitions, ${ }^{191}$ so too might they provide intuitions for finding and repairing private action problems.

For example, is there a "weakness theory" analogous to the intuition animating the power theory? Where the government's coercive capacity is weak, that is, where it is unusually similar to that of ordinary market actors, the application of public Constitutional Law lacks its ordinary justification. ${ }^{92}$ If the government is just another employer in a competitive labor market, is buying and selling in the market like ordinary market actors, ${ }^{193}$ has as its mission to serve an individual's

staff have a job to do, and the governor justifiably feels that a quieter subordinate would allow them to do this job more effectively.").

188. 391 U.S. 563, 568 (1968).

189. See, e.g., Waters, 511 U.S. at 675 (explaining that the fact that it is acting as an employer permits a governmental entity to regulate in the name of efficiency).

190. See, e.g., Connick v. Myers, 461 U.S. 138, 149 (1983) ("While as a matter of good judgment, public officials should be receptive to constructive criticism offered by their employees, the First Amendment does not require a public office to be run as a roundtable for employee complaints over internal office affairs.").

191. See supra Section III.A.

192. See Strauss, supra note 105, at 416 (arguing that when the government is subject to ordinary market forces it should be subject to less stringent constitutional scrutiny).

193. The private action problem sheds light on the market-participant exception to the 
private purpose, ${ }_{194}^{194}$ or is otherwise appropriately acting as a selfinterested entity, ${ }^{195}$ courts should and do import private secondary rules to displace more searching public rules.

I do not attempt to give a full account of private action problems in this Article. But these examples show how difficult cases, the odd outcroppings, can be understood better with a full appreciation of law's public-private bedrock.

\section{CONCLUSION}

The institutional perspective on state action provides a firm theoretical foundation for the doctrine. It reveals that the state action question is found in areas of law other than the body of recognized state action cases. It explains the political and common law regulation of private conduct with public-type norms. It explains the focus in state action cases on discrete and insular minorities. It connects the rather odd but important smattering of state action cases with the deeper structure of legal systems. While it does not render every state action question easy, it at least has the virtue of showing why they are hard.

State action, conversely, demonstrates the importance of apprehending law's public-private structure. The structural theory, by focusing on the fundamental division between collective and individual action, helps reduce a great many seemingly unrelated substantive questions to different aspects of the same underlying institutional question. For this reason, the light it shines on state action can similarly illuminate other areas of our law. Because the structural theory is general, applicable to any collective, and because the institutional state action theory is cast in terms of the structural theory, we now have the

Dormant Commerce Clause cases. See, e.g., Coll. Sav. Bank v. Fla. Prepaid Postsecondary Educ. Expense Bd., 527 U.S. 666, 685 (1999) ("[T]he prospect that States will use custom duties, exclusionary trade regulations, and other exercises of governmental power . . . to favor their own citizens . . . is entirely absent where the States are buying and selling in the market."); Reeves, Inc. v. Stake, 447 U.S. 429, 436, 446 (1980) (upholding South Dakota's decision to sell the product of a state cement plant on a priority basis to South Dakota citizens and distinguishing "between States as market participants and States as market regulators").

194. See, e.g., Polk Cnty. v. Dodson, 454 U.S. 312, 318-19 (1981) (holding that stateemployed public defender was not subject to constitutional torts under 42 U.S.C. § 1983, as the defender serves "essentially a private function" of advancing his or her client's interests).

195. See, e.g., Ball v. James, 451 U.S. 355, 370 (1981) (refusing to apply the one person, one vote rule of Reynolds v. Sims, 377 U.S. 533 (1964), to an Agricultural Improvement and Power District). The Court in Ball decided, based on the limited powers and mandate of the District, that the nonvoting members and the District - despite its formal, public status - had a consumer-business relationship rather than a citizen-sovereign one. "The functions of the [District] are therefore of the narrow, special sort which justifies a departure from the popularelection requirement of the Reynolds case." Id. 
tools to look for state action problems in other types of legal systems. For example, in international law, is there a state action theory that should be applicable to treaties, or other rules made by the private entities (states, here) within the system that raise state action problems?

I have endeavored to use the tools of the structure theory to develop a fuller picture of the state action problem. This is only a beginning, both to filling in that picture and to developing the public-private theory of legal systems. 
